\title{
Black Protests in the US, 1994-2010
}

Keywords: Black movements, African American movement, protest event analysis, news media coverage of protest, protests about police violence

Pamela Oliver, University of Wisconsin - Madison

Pamela.Oliver@wisc.edu orcid.org/0000-0001-7643-1008

Chaeyoon Lim, University of Wisconsin - Madison

chaeyoon.lim@wisc.edu orcid.org/0000-0003-4527-4390

Morgan C. Matthews, University of Wisconsin - Madison

mmatthews5@wisc.edu orcid.org/0000-0003-2721-1572

Alex Hanna, DAIR Institute

alex.hanna@gmail.com orcid.org/0000-0002-8957-0813

Acknowledgements: This research was funded by National Science Foundation grants SES1423784 and SES 1918342. This paper is an extensively revised version that includes updated and corrected data of papers previously presented at conferences in 2017 and 2019.

This is a preprint of "Black Protests in the United States, 1994 to 2010" (2022) Sociological Science 9:275-312 which is available in open access at http://dx.doi.org/10.15195/v9.a12 Please cite the published version.

\begin{abstract}
Using novel data, we provide the first panoramic view of US Black movement protest events as reported in US newswires between 1994 and 2010 and put our quantitative data into dialog with qualitative accounts. Struggles during these years presaged the Black Lives protest waves of 2014-2016 and 2020. Protests increased after the 1995 Million Man March into 2001, but dropped abruptly after the $9 / 11$ attacks. Collective action increased again at the end of the 2000s. Protests in response to police violence and other criminal legal issues were major arenas of struggle and news coverage. Also common were issues of national identity including celebrations of Black history and Black solidarity, protests about Confederate symbols, and protests about White hate groups and hate crimes. While Black people protested about a wide variety of issues, newswires focused disproportionately on incidents of police violence and perceived threats of Black violence. There is substantial continuity in issues, organizations, and activism between this earlier period and the Black Lives Movement of 2014-2020.
\end{abstract}

Content warning: parts of this article describe incidents of police violence. 


\section{Black Protests in the US, 1994-2010}

\section{INTRODUCTION}

When the Black Lives Movement ${ }^{1}$ (BLM) emerged in 2014, many popular discussions compared it to the Civil Rights era, implying there had been no Black movement since the 1960s. Even some academics skip over these decades in describing continuities between the Civil Rights and Black Lives movement eras (e.g., Francis and Wright-Rigueur 2021, Manchanda and Rossdale 2021, McKersie 2021, Nummi, Jennings and Feagin 2019), and there is relatively little scholarship on the Black movement around the turn of the millennium. We use unique, newly collected data on Black protest events from 1994 to 2010 to provide the first panoramic view of Black activism in this period. We describe both the "big" events and issues and the diversity of less newsworthy events and issues. Our agenda is unapologetically descriptive: the Black movement in this period is intrinsically interesting and theorizing about the Black movement needs a stronger empirical base. Overall, we show that the Black movement was building in the late 1990 s before being temporarily stalled by the $9 / 11$ attacks, and that Black mobilization of the 1990s and 2000s appears to presage the Black Lives movement of 2014 and after.

People in the United States actively struggle over the collective memories of its racial history. As Fleming and Morris (2015) stress, memories of the past are relevant for current demands, as oppressed people seek to memorialize their suffering and struggle while their opponents seek to downplay past conflicts. As we write, a political movement seeks to ban the teaching of the "critical race" idea that the U.S. has racist foundations (Goldberg 2021, Ray and Gibbons 2021). The history of the Civil Rights era itself is contested, with the dominant White ${ }^{2}$ memory locating racial oppression safely in the past and celebrating Dr. King as a nonconfrontational teacher of colorblindness (Theoharis 2018), a sanitized view that has been deployed as a criticism of the Black Lives movement (e.g., Jackson 2021). In this White-centric view, the Black Lives Matter protests of 2014-16 and 2020 seem to be wholly new.

Scholars who call for "Black theorizing" of the Black movement similarly criticize an academic collective memory of the 1960s Civil Rights Movement (CRM) that centers on the South and nonviolent protest. Bracey (2016) argues that "mainstream" treatments of the Black movement employ White-centric assimilationist assumptions, where integration is the only goal. In contrast, a critical race frame "facilitates goals ranging from separatism to complete integration and reparations" (p. 17). He argues that race riots, cultural movements, and separatist movements are all part of the Black movement. Similarly, Fleming and Morris say, "The major problem oppressed groups face is the lack of power" (2015:108) and argue that disempowered groups seek to alter their conditions through disruption but must overcome cultures of submission. This explains why "urban revolts and a nonviolent CRM ran along parallel tracks throughout the early and late 1960s with King and Malcolm X's followers competing to direct the Black freedom struggle" (p. 111). Theoharis (2006) similarly stresses the integration of Southern and Northern struggles, local organizing, the broad diversity of ideologies, and the interrelation of nonviolent protest and insurrection.

Academic memories of the 1960s are directly linked to the broader "critical race" (Bell 1980, Randolph et al. 2019, Ray et al. 2017b, Weddington 2019) question: did the Civil Rights movement win permanent victories or was it one moment in an ongoing history of struggle that 
continued after 1965? Was the BLM a new movement or a continuation? Were the decades between an interlude between movements or was the movement continuous? More specifically, what happened in the 1990s and 2000s? To address this question, we analyze mainstream Whitedominant news sources. We treat these sources both as artifacts providing evidence about what happened and as texts actively constructing representations of events. We attend to the focus of the White gaze as we report which events received extensive coverage. We show that the newswires disproportionately focused on incidents of Black resistance to police violence and to incidents involving perceived threats of Black violence. This is consistent with the recent mainstream news media focus on anti-police protests and under-coverage of broader proactive Black activist agendas.

\section{Black Movement Abeyance and Continuity}

Black protests in the news declined after the victories of the Civil Rights Movement in the 1960s, as shown in Figure 1, calculated from the Dynamics of Collective Action (DCA) data on protests reported in the New York Times from 1960 to 1995 (Soule et al. n.d.). Amenta et al. (2009) draw the same conclusion about New York Times coverage of movement organizations 1900-1995. The Black movement continued but was much less often in the news.

\section{FIGURE 1 ABOUT HERE}

Protests declined as the tactical preferences of Black people changed. Especially after the murder of Dr. King in 1968, Black support for non-violent protest declined in favor of either more militant actions or more institutional actions (Santoro and Fitzpatrick 2015). Black nationalist sentiments rose, partly captured by the rapid decline of "Negro" and rise of "Black" as the preferred racial group designation, accompanied by an emphasis on Black pride and Black culture. The Black Panthers and other Black Power activists initially advocated armed selfdefense in addition to their community development programs, but by the mid-1970s were focusing on developing political and institutional power (Bell 2014, Bloom and Martin 2013, Johnson 2007). Black groups sought to build Black power in conventions of the 1970s (Johnson 2007), which fed into Jesse Jackson's Rainbow Coalition campaigns and electoral activism in the 1980s (Jennings 2000, Lawson 2014). For their part, White politicians and movements pushed back against the gains of affirmative action and Black political empowerment from the 1970s on (Lawson 2014, Marable 2007, Musgrove 2012). Robnett (2020) documents how the NAACP and other Civil Rights organizations were undercut in the 1970s and 1980s by race-blind rhetoric that portrayed the battle for racial equality as won and attempts to advance Black agendas as unnecessary and even racist.

Although movements are often seen as dying when protest mobilization declines, social movement scholars draw on Taylor (1989) and the concept of abeyance to discuss the ways movements maintain themselves in inhospitable political climates. "Second wave" feminism of the 1970s was connected to ongoing feminist traditions through these abeyance structures (Cullen and Fischer 2014, Nelson 2021, Rupp and Taylor 1987, Whittier 1997). Similarly, scholars have documented ongoing resistance by Black Americans prior to the burst of 1960s Civil Rights protests (Burke 2020, Felber 2020, Fujino and Harmachis 2020, Kelley 2010, Morris 1984, Nichter 2014, Nichter 2021, Stillerman 2020, Williams 2015) while recognizing the distinctiveness of each era (Cha-Jua and Lang 2007). 


\section{Documenting Black Activism in the 1990s and 2000s}

While the Civil Rights and Black Power eras are well-documented, and there are many new studies of Black Lives Movement protests and groups since 2014, there is a notable gap in quantitative studies of Black movement activity after the 1960s. DCA and other data that extend into the 1990s have been used to explain the decline of Black protest after the CRM (Jenkins, Jacobs and Agnone 2003, McAdam 1982, McAdam 1983, McAdam et al. 2005), but not to describe what the Black movement did do after the 1960s. Rafail and colleagues compiled protest events in 20 local newspapers for 1996-2006 (Martin, Rafail and McCarthy 2017, Rafail 2018), but no papers from this project so far address Black protests specifically.

Qualitative historical accounts of this period are also sparse, as Musgrove (2019) notes. The most comprehensive accounts are later chapters in Marable's (2007) history of the Black movement and Lawson's (2014) Black political history. Musgrove (2019) describes Panther-like formations including the New Black Panther Party and locates them in the broader post-1970s Black Power and Black nationalist movements. Richie (2012) describes organizing by Black and other women of color around issues of violence and criminal justice, including the formation of INCITE! and Critical Resistance in the late 1990s. Brewer (2003) discusses radical Black organizations of the 1990s and early 2000s emphasizing interrelations of race, gender, and class politics. Johnson (2007) mentions some events from the 1990s and early 2000s. Taylor (2016) and Ransby (2018) focus on the immediate predecessors in the early 2010s of the BLM in local grassroots and radical organizations but include some discussions of earlier decades. Oliver (2020) describes ongoing struggles around the criminal legal system. We refer to these overviews and to studies of specific groups or events in discussing our quantitative results.

Building on these qualitative accounts, we address the following questions: What issues and groups were visible in mainstream, White-dominant news? Which were not, or only vaguely referenced? Did these actions of the 1990s and 2000s connect with what came later? If so, how?

\section{DATA AND METHODS}

We used a hybrid machine-human system to identify protests by Black people or about Black issues in articles from U.S. newswire sources (Associated Press Worldstream, New York Times, Los Angeles Times/Washington Post) for 1994 to 2010 that are compiled in the Annotated English Gigaword (AGW) database from the Linguistic Data Consortium. ${ }^{3}$ Details about our data collection methods are available in Oliver, Hanna and Lim (2021). We created a dataset that links each event to all the articles that mention the event and took several steps for checking and correcting the data. Our search terms emphasize protests and the overt mention of the words Black or African American. Consistent with Bracey (2016) and Fleming and Morris (2015), we used inclusive and expansive definitions of both protest and Black movement in identifying events to encompass everything that either involved the visible presence of African Americans or involved issues relevant to African Americans. Counter-protests and non-Black events linked to Black events were also recorded. Although we did not search directly for White supremacist events, we keep them in the data because many involved reactions by Black actors and they are relevant to ongoing racial contestation. Our methods explicitly recognize ambiguities in counting protests: protests are often fluid and evolving, multiple distinct actions by different groups are often parts of a larger whole, and news stories about events are often cryptic or ambiguous. For the descriptive purposes of this paper, we focus on identifying 
important patterns and trends, not rigorous issues of counting, and conduct most analysis at the level of specific issue clusters, described below.

We believe that both people's actions and how they are described in news media matter. We paint our descriptive picture in issue clusters, events, articles, and participants. We identified 432 issue clusters involving 1,342 events described in 1,210 articles involving between 4.6 and 13 million total participants. News coverage of events is highly skewed. Although $69 \%$ of the events were mentioned only once, four events were each mentioned in more than 40 news articles. ${ }^{4}$ The 14 most frequently mentioned events ( $1 \%$ of the total) accounted for $17 \%$ of the news mentions of events while $16 \%$ of the events accounted for half of all news mention of events.

Reported counts of participants are notoriously vague or inaccurate and often contested. We present ranges of participant numbers, not point estimates, using all available information in the articles, including not only numerical estimates but also phrases such as "busloads of protesters" or "filled ten blocks," vague indicators of size such as "a few" or "a crowd" or "thousands," and contextual cues. The minimum size estimate is zero for future or threatened events that may not have happened.

We treat news media as active producers of meaning in interaction with the protest movements seeking media attention (Vliegenthart and Walgrave 2012) and draw on the extensive literature about how mainstream news media cover protests (see Brasted 2005 for a review). Journalists often use a protest paradigm that emphasizes social disorder, relies disproportionately on official sources, and invokes public opinion to portray protestors as deviant. We attend to the mutual relations between media and movements that lead to media attention cycles (Seguin 2016): activists intentionally seek to draw news coverage and success in gaining news coverage can lead to more protest.

\section{Specific Issue Clusters}

We focus our analysis on what we call specific issue clusters. News articles describe protest events as being about specific issues, such as the New York police killing of Amadou Diallo, a proposed anti-begging ordinance in Atlanta, or accusations of discrimination by the Adams Mark hotel chain. A set of events about the same specific issue is a specific issue cluster. Events can logically belong to multiple specific issue clusters, but for this paper we attribute each event only to its primary or overarching cluster. Although most specific issues are represented by only one event and covered by only one article, a few specific issues involve many events or participants or are covered in many articles.

Specific issue clusters with multiple events are often (but not always) the textual representations of what social movement scholars identify as campaigns or episodes. A campaign is a series of protests around the same issue, often intentionally planned by a group of activists, like the iconic Albany and Birmingham campaigns in the Civil Rights Movement (Morris 1984). An episode is an action-reaction sequence as protesters and their opponents or targets respond to each other's actions (Franzosi 1999, Kriesi, Hutter and Bojar 2019, McAdam, Tarrow and Tilly 2001, Wada 2004). A reader of a news story cannot necessarily identify the causal action-reaction relationships that define episodes nor the intentionality that often defines a campaign, but they can tell that the news stories described events as being about the same issue. 
The 21 most newsworthy clusters are listed in the online supplement, Table A1 and discussed below.

\section{RESULTS}

We begin with an overview of the Black movement events we identified, including when they occurred, which actors and organizations appeared in newswire coverage of them, and what issues they addressed. We then narrate Black movement activities during this period as they appeared in the newswires. We discuss highly covered protests about police violence and large mobilizations such as the Million Man and related marches. Then, we describe struggles over White dominance, which include protests over Confederate flags, reparations, and affirmative action. Finally, we discuss the less well-covered coalitional and other issues in the data. Throughout, we put the newswires into dialog with qualitative historical accounts.

\section{Timing of the Protests}

Figure 2 shows the monthly counts of events, articles, and participants from 1994 to 2010. The clearest pattern is the precipitous drop in protest events and articles after the 9/11 terror attacks, marked by the dashed vertical red line. The negative effect of 9/11 on the Black movement is mentioned by several sources (Fletcher and Rogers 2014, Marable 2007, Taylor 2016), although they give different explanations for it. Marable emphasizes heightened repression of all progressive and anti-war movements, and stresses Black support for Muslims (about a quarter of whom in the US were Black). Taylor describes the campaign against racial profiling losing steam with the shift toward profiling Muslims, which many Black people supported. Fletcher and Rogers put more emphasis on organizational disarray in the Black Radical Congress. Additionally, news media emphasis on the terror attacks would create a "news hole" effect (Oliver and Myers 1999, Oliver and Maney 2000), reducing news coverage of other things, including Black protests.

The participant graph is dominated by brief spikes in participation from occasional events with hundreds of thousands of participants that do not generally coincide with the peaks of events and articles. On this scale, events with thousands or even tens of thousands of participants look small, but the graph reinforces the point that raw numbers of participants are not the biggest factor driving news coverage. Numbers of articles and numbers of events track each other more closely. ${ }^{5}$ The months with large spikes in articles but smaller spikes in events track highly newsworthy events we discuss below, including the Million Man March and the Freddy's arson/murder in 1995, the Diallo protests in 1999, the death of Rosa Parks and $50^{\text {th }}$ anniversary of the Montgomery Bus Boycott in 2005, and the Jena 6 mobilization in 2007.

\section{FIGURE 2 ABOUT HERE}

Events and news coverage come in bursts, but there are more protests and coverage before 9/11 than after and some hint that there might have been a rising protest wave in 2000 and 2001 that was cut short. Events start increasing again from 2005-08, but at a lower level than before. There is no way of knowing whether the trend before 9/11 would have continued or accelerated into a movement takeoff or scale shift (McAdam, Tarrow and Tilly 2001:331). However, this temporal pattern is consistent with historical accounts. The Rodney King beating and the huge Los Angeles insurrection in 1992 evoked a great deal of public discussion of race and police brutality as well as a raft of social science articles. This case generated energy and 
anger among Black people and fed into the huge 1995 Million Man March, which inspired further action among many people. Several sources describe growing racial consciousness and the formation of new organizations as the 1990s progressed (Brewer 2003, Fletcher and Rogers 2014, Marable 2007, Musgrove 2019, Taylor 2016).

\section{FIGURE 3 ABOUT HERE}

Figure 3 compares our event counts from the Black Protest Project (BPP) to those in the DCA for Black issues or actors. Even though the methods and the sources are different, the figure suggests 2000-01 had unusually high activity and was perhaps comparable to the early 1970s. Of course, this peak is far below the event counts observed from either the 1960s or 2014-2020 (Lu 2020, Robinson 2021)

\section{Event Types and Issue Groups}

Table 1 shows how we grouped specific issues into researcher-defined broader issue categories and the number of events in each, by event type. A Black event is one in which Black people are visible central actors or supporting Black people is the central issue. All issue clusters involve at least one Black event. An anti-Black event either is a counter-protest to a pro-Black event or an event centering White identity politics. Although we did not directly search for White supremacist events, they often appeared in our newswire searches. The "Other" event type category is events that neither center nor oppose Black people or issues but have visible Black participation or were part of an issue cluster that included Black-centric events.

\section{TABLE 1 ABOUT HERE}

Figure 4 visualizes these same issue groups with the percentages of specific issue clusters, events, articles, and minimum participants. ${ }^{6}$ Several things stand out. First, the issue groups with large participant counts are different from those with large numbers of events or articles about them. Events with many participants concern Black solidarity, coalitional issues like abortion or welfare or gay rights, and events tied to politics. Second, the single largest category of issue for events and news articles is police violence, and other criminal-legal issues were also prominent. Confederate symbols, White identity groups, and inter-group violence also stand out. These issues are still on the table today. Issues involving proportionately fewer events, participants, or articles included history, workers', and local issues. The broad categories "local" and "other" capture a diversity of specific issues for which no more specific category stood out. Table A2 in the online supplement gives a more detailed breakout of these issue groups. As we work through the issues Black people protested, we attend to whether those protests were reactive, i.e., responding to a grievance and threatened loss created by the government or others, or proactive, i.e., seeking to gain new advantages, where the protesters choose the terms of engagement (Shemtov 1999, Stone 2016).

\section{FIGURE 4 ABOUT HERE}

\section{Big Names and Organizations}

We used keyword searches of the full texts of newswire articles to determine whether they mentioned names of Black or ally groups, or Black leaders identified in preliminary analysis as having been frequently mentioned, eliminating redundancies as appropriate. Table 2 summarizes the information about the activists and organizations named around multiple issue 
clusters. Consistent with Seguin (2016), only a few people and organizations dominate the news. The NAACP, Al Sharpton, and Jesse Jackson together account for 45\% of event mentions, $41 \%$ of events, $41 \%$ of articles and $33 \%$ of issue clusters. The other people or organizations listed in the table added another $14 \%$ to the totals of 59\% for event mentions, $55 \%$ for events, $55 \%$ for articles, and $47 \%$ for issue clusters. Our preliminary analyses (online supplement Table A3) suggest that most of the "big names" were generalists associated with many issues, both organizing their own events and lending support to an issue organized by others. About twothirds of the instances of mention of Al Sharpton involved events in New York; otherwise mentions were geographically dispersed. Rosa Parks and Coretta Scott King were mostly associated with historical commemorations, although Parks' name was often invoked symbolically across a range of issues. ${ }^{7}$ Most of the coverage of Farrakhan centered on the Million Man March (discussed below).

\section{TABLE 2 ABOUT HERE}

The New Black Panther Party (NBPP) and its leaders Khalid Abdul Muhammad and Malik Zulu Shabazz may have received extra attention relative to their size due to perceived dangerousness. Muhammad and Shabazz began in the NOI but in the mid-1990s moved to the NBPP_founded earlier in 1993 by Michael McGee from Milwaukee_-and "Islamified" it after 1996 (Musgrove 2019). Muhammad (who died in February 2001) gave anti-Semitic speeches and was condemned as a dangerous extremist by White authorities; much of his coverage centered on the Million Youth Marches (discussed below). Shabazz took leadership of the NBPP after Muhammad's death. The NBPP and its leaders were mostly associated with issues of police violence and White supremacists.

\section{The Biggest Stories: Policing and the Criminal Legal System}

Police violence and interpretations of disorder in response to police violence have long been central issues for Black protest (Abu-Lughod 2007, Baggetta and Myers 2021, Button 1978, Hinton 2021). Protests described as "riots" provoke more negative public responses than protests described as peaceful (Kilgo and Mourão 2021). An analysis of DCA data finds that greater use of force and arrest for Black protesters is largely because the police are more aggressive toward anti-police protesters (Reynolds-Stenson 2017).

The 1991 beating of Rodney King by four Los Angeles police officers and the 1992 failure to convict the officers even with video evidence was seen by many as evidence of the intractability of White supremacy and spurred much Black activism. Clinton's 1994 anti-crime bill increased funding for police and prisons (Beckett 1997, Chambliss 1995). The widelydiscussed 1994-5 OJ Simpson case also impacted Black and White discourses about race and policing (Cossack 1996, Grabe 2000), although no protests about it appear in our data.

In our newswire data, the $18 \%$ of specific issues that are about the criminal legal system account for $30 \%$ of the events and $38 \%$ of the news articles, with specific incidents of police violence alone accounting for $20 \%$ of events and $25 \%$ of articles, but $8 \%$ of issue clusters. Six large specific issue clusters (1\%) about incidents of police violence alone account for $13 \%$ of the events and $18 \%$ of the news articles in our corpus. These included four incidents in New York and one each in Cincinnati and Oakland. Protests about specific incidents of police violence are always initially reactive. In a few cases, activists became proactive in choosing the tactics and timing of their protests. 


\section{New York}

Four New York incidents of police violence were addressed in 124 newswire stories, $10 \%$ of the total. This was a politicized context: overtly pro-police Republican Rudy Giuliani became mayor in 1994 after defeating Democrat David Dinkins, New York's first Black mayor, who had angered police in attempting reforms. New York had been using aggressive policing of both protests and "broken windows" disorder since the 1980s (Rafail 2015).

The first incident was the brutal torture and rape of Abner Louima in 1997 by a police officer in a precinct bathroom. Twelve news stories covered protests before the officers involved were charged and events in 1999, after the officers convicted for watching the torture and not intervening won appeals. Although no one defended the torture, articles covered debates about whether this was an isolated incident or part of a broader pattern of police aggression and impunity that had been empowered by Giuliani.

The most eventful and newsworthy New York episode involved police officers shooting 40 rounds of bullets into Amadou Diallo in February 1999 as he stood on his front porch holding only a cell phone. A total of 76 news articles described the 62 events in this cluster. Although the initial protests were reactive, they quickly became planned and tactically proactive. Frequent protests in February were followed by daily ritualized blockades of the police station in March that involved the orchestrated arrests of public officials and celebrities. Articles emphasized politics and Giuliani's refusal to meet with Black leaders. Periodic protests continued after the police were indicted, and there were more protests after the police were acquitted in January 2000 .

Two additional New York police killings occurred in 2000 during the Diallo protests. Eleven articles described protests after the killing of Patrick Dorismond by undercover narcotics police after he angrily refused when they asked him to sell them drugs. Dueling accounts debated whether the brawling between police and protesters after his funeral was initiated by protesters or caused by police seeking to contain too many people within too small a space behind their barricades. The police killing of Malcolm Ferguson within a few weeks of the Dorismond killing received less coverage but was also discussed in the context of the Diallo case. Most of the victims of these police killings were immigrants, a fact stressed by Layne (2021) in discussing the importance of Black immigrants in the Black struggle. In the wake of the Diallo protests, there were protests and a hearing in Washington in 1999-2000 calling for addressing the issue of

police violence more generally. These were mentioned in the newswires but did not get extensive coverage.

The last big New York police killing story (25 articles) occurred in 2006, when Sean Bell was killed the night before his wedding as undercover officers shot into his car. Protests, including a large march of 50,000 people, led to the officers being indicted. Extensive planned disruptive protests followed the officers' acquittal in 2008, including coordinated simultaneous blockades of six New York bridges and tunnels.

Over time, the newswires came to treat Al Sharpton as the key player in these New York protests. He was mentioned in 58\% of the stories about the Louima episode, $72 \%$ of the articles about the Diallo episode and $96 \%$ of the articles about the Bell episode. Past New York protests about police killings doubtless shaped the 2014 New York protests about the police killing of Eric Garner. Two weeks after Garner was killed, Sharpton visited Ferguson, Missouri, the day after a police officer killed Michael Brown. 


\section{Cincinnati}

Just behind the Diallo episode with 73 news articles and 50 events was the "Cincinnati riot" story, which was repeatedly described in the newswires as the largest urban disturbance since Los Angeles in 1992. McDaniels-Wilson, Jeffries and Upton (2012) insist it should be understood as an uprising against systems of oppression. In April 2001, a Cincinnati police officer fatally shot Timothy Thomas in the back as he was running away; Thomas had been stopped by police often for petty violations but had committed no serious crimes. Two weeks before, the Cincinnati Black United Front and the ACLU had filed a lawsuit over violent and discriminatory policing in response to prior police killings and other incidents. After the Thomas killing, the NAACP joined the lawsuit, and its settlement became intertwined with protests in news stories. Newswire stories about protests in the initial days were vague and confusing, with disorder being the main story. There were angry calls for accountability at the city council on the Monday after the killing and several protest marches. Newswire accounts suggested but never said directly that police were aggressively blocking peaceful protests and attacking non-rioters. A few stories described police shooting pellet-filled beanbags at people standing around peacefully after the victim's funeral, but none cited any official comments about the incident. The Rev. Al Sharpton, NAACP president Kweisi Mfume, Martin Luther King III, Malik Zulu Shabazz and others from the New Black Panther Party, and representatives of the Nation of Islam all attended Thomas's funeral, while Jesse Jackson was quoted from a phone interview. After the initial four days, protests continued along with community forums, meetings, and a call for a tourism boycott. Although a few protests were covered, newswire coverage emphasized city officials' responses in the context of the "riot." The lawsuit was finally settled in 2002. The results are often hailed as an example of positive police reform (MacDonald et al. 2007, Rothman 2006, Schatmeier 2012).

The Cincinnati Black United Front (CBUF) had sought to shift to a proactive mode with its lawsuit and alliance with the ACLU, but they lost control to other actors. Two accounts say officials ignored the CBUF in developing reforms (Hogan 2001, Hood 2020) and newswires mentioned the ACLU more often than the CBUF. McDaniels-Wilson, Jeffries and Upton (2012) report ongoing grievances in a survey ten years later, a claim also made by Hood (2020). There are several case studies of the news coverage of the Cincinnati events (Campbell et al. 2004, Lachlan et al. 2007, Steijns 2017) and of the effects of the uprising on policing (Shi 2009). Overall, media treatment of the Cincinnati uprising was a muted version of the response to the Los Angeles uprising and presaged some of the response to the Ferguson uprising of 2014.

\section{Oakland}

On New Year's Day 2009, Oakland transit police officer Johannes Mehserle threw Oscar Grant to the ground, handcuffed him, shouted a racial epithet, and then shot him in the head. Bystanders video-recorded the killing on their cell phones, ushering in the era of video-recorded police murders. Protests were initially ignored by both the newswires and the authorities until a peaceful march turned into a riot, and then the riot became the story, along with the decision to indict the officer. In 2010, after Mehserle was found guilty of a lesser charge and given a light

sentence, there was another round of community protests that were said to have turned into riots. The 24 newswire stories about the 16 events emphasized police efforts to control rioters and plans to prevent future rioting and gave no coherent account of peaceful protests. Other sources offer a different picture. In a series of contemporaneous blog posts, political scientist George Ciccariello-Maher (2009a, 2009b, 2009c, 2010) says that peaceful protests by local groups were 
ineffective in getting the authorities to charge Mehserle, that much of the "rioting" was by White people from outside Oakland who could not be controlled by the local protesters, and that only the rioting got any attention. There is no evidence of a proactive turn in this episode, although Rios (2015) reports that some of the youth he studied in the Bay Area turned toward collective resistance after the killing of Oscar Grant.

\section{Other Cities}

Newswires reported but gave much less coverage to an additional 40 episodes in 28 cities of protests about police violence, usually killings, accounting for $7 \%$ of the events and articles. As several groups have made efforts to document police killings more systematically since 2014, it has become clear that there are many more police violence incidents and protests about them covered in local news that never make it into national news.

\section{Other Criminal Legal Issues}

There were many protests about other aspects of the criminal legal system, including complaints about discriminatory policing charging of Black people, failure to charge White people for hate crimes, and the death penalty. The biggest story was the Jena 6 , covered in 65 articles. This episode began with White students hanging nooses on a tree at an integrated Jena, Louisiana high school in September 2006 after Black youths sat under it. Initial protests about failure to punish the noose-hangers were not covered in the newswires; neither were the series of fights between Black and White students, nor the initial protests about charging six Black youths with attempted second-degree murder after they beat a White youth. ColorOfChange.org began organizing an online campaign in the summer of 2007 to draw attention to the issue. It organized a large march of 20,000 people in Jena for September plus solidarity protests in many cities around the country on the same day. The first newswire story appeared on July 31, after which it became a big media event. The Jena 6 mobilization was not the first sustained protest about overcharging in our data: in the fall of 1999, Jesse Jackson led a series of protests in Decatur, Illinois about over-charging high school students after a fight at a school football game that were covered in 10 news stories.

In the wake of the Jena 6 mobilization, there was heightened coverage of noose-hanging incidents and protests about them, as well as protests calling for stronger penalties for noosehangings and other symbolic hate crimes. We treat the 15 news stories about 15 incidents of nooses in the fall of 2007 as a different issue cluster from Jena 6, although several events referenced both issues. The call for strengthening penalties for hanging nooses and other symbolic hate crimes was a possible proactive turn.

Another criminal legal issue involving 29 events and covered in 23 newswire articles was the ongoing campaign against the death penalty for Mumia Abu-Jamal, who had been sentenced to death in 1982 for killing a police officer, which Abu-Jamal said he did not do. These protests recurred periodically between 1994 and 2010 and included five pro-police counter-protests. Angela Davis mentions this as a major campaign (Davis 2016). Four other death penalty issues received less news coverage.

Apart from these more widely covered issue clusters, there were 29 other clusters around discriminatory policing or charging or the death penalty that got some mention. The ACLU and the NAACP were also building proactive campaigns against racial police profiling at the end of the 1990s, when the phrases "driving while Black" and "racial profiling" were common in discussions and academic publications. These campaigns involved research studies more than 
protests and mostly do not appear in our protest-centric data, although there were a few protests about discriminatory traffic stops and policing in general that received modest newswire coverage. Although not covered by the newswires, both INCITE! and Critical Resistance were founded at the end of the 1990s and developed ideologies around the state violence and prison abolition that fed into the BLM.

Overall, the protests of 2014-16 and after the 2020 killing of George Floyd, as well as the broader campaigns for police reform, defunding the police, and prison/police abolitionism, clearly built on a longstanding pool of grievance, patterns of protest, and organizing.

\section{Million Man March and Related Large Events}

The 1995 Million Man March was large, newsworthy (60 newswire articles), and important. Some call it the largest Civil Rights or Black movement event in US history. It built on popular Black nationalist sentiments that increased after the 1992 acquittal of the police who beat Rodney King (Marable 2007, Musgrove 2019, West 1999). Called by Louis Farrakhan of the Nation of Islam, the march's stated purpose was to call Black men to repentance and responsibility for families and communities, although Farrakhan's speech also criticized a culture of White supremacy. It made no explicit demands on government or White people. Some Black Christians, feminists, and leftists opposed the march on ideological grounds, but a large majority of Black people supported it (Marable 2007, Musgrove 2019). Anticipatory coverage by mainstream (White) network television news shows included framings of threat or deviance (Watkins 2001). The march proved to be upbeat and celebratory. Rosa Parks spoke briefly, along with many other prominent Black people. There was a controversy at the time about estimates of the crowd size ranging from 400,000 to 1.1 million, with higher estimates being more likely. We categorize this as a "Black solidarity" issue and group it with other events whose purpose is to bring Black people together. All our historical sources and some of the newswire stories discuss how the March itself and the mobilization around it galvanized the Black movement. There were smaller events around the country on the first and second anniversaries of the big march.

Newswires covered anniversary events in many cities for the first few years and printed a few articles about instances of Black groups organizing for volunteering and civic development. Manning Marable and other Black radicals organized the Black Radical Congress (BRC) in response to the energy it generated and their dismay that Farrakhan's conservative politics were at its center (Fletcher and Rogers 2014); newswires did not cover the BRC.

Two other large events followed and built on the "Million" theme and received significant newswire coverage. The 1997 Million Women March in Philadelphia, described in seven articles, was organized by two Black Philadelphia grassroots activists who centered concerns of poor Black women in a 12-point platform that addressed issues including education, imprisonment, drugs, and violence. Attendance estimates ranged from 300,000 to 1.5 million. West (1999) says the Million Woman march was a radical rejoinder that contributed to the momentum toward the Black Radical Congress. In these data, we group it in a cluster with other 1997 events commemorating the Million Man March. In March of 2000, the Million Moms March against gun violence, discussed in eight articles, attracted 300,000 to 750,000 attendees in DC, plus another 150,000 to 250,000 in coordinated marches in other cities. It was organized by a White woman but had significant participation by Black women and contributed to an ongoing movement. We classified it as a coalition event. 
Other "Million" themed events included the 2000 Million Family March, jointly sponsored by Louis Farrakhan and Rev. Moon of the Unification Church, which planned for 300,000 but may have been as small as 20,000; two articles mentioned it. The 2005 Millions More rally commemorating the $10^{\text {th }}$ anniversary of the Million Man March was two months after Hurricane Katrina. It was attended by at least 350,000 people from a broad range of groups, listed many issues of concern, and was mentioned in six articles. Overall, the "Million" movement theme crested in 2000 and largely died down after 2001.

\section{When Violence and Confrontation Became the Story}

The 1998 New York Million Youth March organized by Khalid Muhammad was a big news story because it was repressed. The New York authorities viewed Muhammad as inherently dangerous and sought to block the event as a hate march in 1998 and again in 1999. In 1998, as the permitted time for peaceful rally of about 6,000 attendees expired, 3,000 police officers in riot gear supported by helicopters attacked attendees to disperse them. From the podium, Muhammad urged the attendees to fight back, and a melee ensured. Giuliani claimed that the violence was exactly what he had predicted. Forty-two articles covered the New York Million Youth marches and the attempts to prevent them in 1998 and 1999, with coverage of the peaceful and smaller 1999 and 2000 marches referencing the 1998 events. A few of the articles also mentioned the separately organized peaceful 1998 Atlanta Million Youth March.

Coverage of several other issue clusters that we categorized as about Black solidarity also emphasized conflict or violence. Invitations to Khalid Muhammad were covered as controversies about his anti-Semitic statements. Black spring break festivals in Atlanta and Daytona Beach were covered as controversies about disruptions and policing problems. Other Black solidarity events lacking references to conflict or violence typically received only brief mention.

What we label the $125^{\text {th }}$ Street cluster of 38 news stories centered on an arson-murder. In December 1995, an armed Black man entered Jewish-owned Freddy's clothing store in Harlem, ordered Black customers to leave, then set the store on fire, killing himself and seven other people. The arsonist was revealed to have been among a handful of Black picketers, sometimes including Al Sharpton, who had for several weeks been protesting displacement of Black vendors. There was no newswire coverage of these picketers and only meager coverage of the issue before the murder. After the murder, there was an explosion of newswire stories linking the murder to 24 other events. Coverage debated the mayor's charge that Al Sharpton was to blame and linked the murder discursively to other conflicts. The articles addressed multiple issues in a policy sense, but we grouped them into one cluster because they were discussed together and pegged to the arson-murder. Taken as a whole, the stories stressed the violent potential of economic conflicts over the control of space. Lee (2002) discusses inter-ethnic conflict in the Freddy's incident and the Los Angeles insurrection.

\section{Confederate Flags and Other Struggles Over White Dominance}

White Southerners began to display Confederate flags in the 1960s in response to the Civil Rights movement. In an earlier era, Confederate monument placement was associated with lynching of Black Americans (Henderson et al. 2021). Black activists proactively sought to remove Confederate symbols in the 1990s. These campaigns provoked White resistance and counter-protests and drew substantial attention from the newswires. 
The largest issue cluster involves 61 articles about 33 events that concerned the 2000-01 NAACP campaign to remove the Confederate flag from the South Carolina Capitol building. 46,000 people marched on Martin Luther King Day in 2000, the first time King Day was celebrated in all 50 states, and many news stories covered the big South Carolina protest in this context. The flag conflict lasted for years, including multiple protests and counter-protests and a tourism boycott. A mid-2001 compromise removing the flag from the Capitol itself and placing it on the grounds in front of the Capitol pleased neither side. Protests continued throughout the 2000s. In 2015, after White supremacist teen Dylann Roof murdered nine Black people in a historic Charleston church, the flag was physically removed by Black activist Bree Newsome and officially removed several weeks later.

Although the South Carolina struggle received most of the news coverage, there were also 13 stories about the Georgia flag issue in 2000 and 35 other articles about protests around other Confederate symbols, including Georgia and South Carolina flag struggles in other years. These conflicts were usually initiated by Black activists trying to get Confederate symbols banned or stigmatized. Attempts to remove Confederate symbols and White defense of the symbols came back into the mainstream news after President Trump's inauguration in 2017 and were part of many 2020 protests. These struggles over symbols were and continue to be important to both sides of the struggle as they are about the very definition of the nation.

\section{History}

Most events about history in our data are commemorations or memorials of Martin Luther King, Jr., Rosa Parks, or major events in Civil Rights history. They both celebrate Black solidarity and are part of the struggle over the definition of nation. The newswires covered some White events opposing these memorials, including KKK rallies and blackface parties on King Day, as well as White supremacist counter-protests to truth-telling or reconciliation events.

The campaign to have King's birthday declared a federal holiday began shortly after his death in 1968, was signed into law by President Reagan in 1983 and was first celebrated in 1986. The campaign to gain states' recognition for the holiday involved tourism boycotts of some states, especially Arizona from 1987-1992. The newswires had a flurry of King Day coverage in 2000 , the first year the holiday was celebrated in all 50 states. Rosa Parks died in late October 2005 , shortly before the planned December 2005 celebration of the $50^{\text {th }}$ anniversary of the Montgomery Bus Boycott. Many events in Washington DC, Montgomery, and Detroit were part of Parks's funeral and many more events in early December memorialized both Parks and the boycott. All received significant news coverage.

Fleming and Morris (2015) stress the importance of commemorations as invoking the past to oppose present oppression and produce counter-memories and characterize the creation of the King holiday as a successful struggle. However, Theoharis (2018) argues that the campaign for the King holiday in the 1980s turned him into an icon of color-blindness. Despite initial opposition to the King holiday, President Reagan began quoting King to justify his opposition to affirmative action (New York Times 1986). Bruyneel (2014) describes similar conflicts over the depiction of King in the National Memorial unveiled in the National Mall in 2011. Theoharis also argues that President Bush's order to have Rosa Parks lie in state in the Capitol Rotunda in October 2005 was a distraction only six weeks after the mismanagement of the Hurricane Katrina disaster. 
A few small events in our data involved campaigns to tell the truth about history, often in the context of a process of reconciliation or asking for reparations for some specific local past harm. These received little newswire coverage, even when they encountered counter-protests. The campaign for reparations for the 1921 Tulsa Massacre was ongoing (Messer, Shriver and Beamon 2018), but did not appear in our protest data. Our data also do not include the campaign to make Juneteenth, the commemoration of the end of slavery, a holiday, although that campaign began in the 1990s.

Black people campaigned for slavery reparations both in the US and globally in the 1990s and early 2000s. The National Coalition of Blacks for Reparations in America (N'COBRA) was founded in 1987 and the NAACP named reparations a top priority in 2001 (Fleming and Morris 2015). Randall Robinson's best-selling The Debt (2000) sparked public debates in the US. International campaigns for reparations for slavery and colonialism built towards the UN conference on racism held in Durban, South Africa in 2001. The only mention of these campaigns in our newswire data is two articles about a small rally and an associated lawsuit and media campaign in 2002. Most (9) articles in our data about reparations were in one issue cluster: in early 2001, David Horowitz sought to place inflammatory anti-reparations ads in college newspapers, sparking student protests.

\section{Affirmative action}

Affirmative action is a struggle over interests and the meaning of history. The Black movement was put on the defensive by elite White pushback and the shift to color-blindness as early as the mid-1970s (Lawson 2014, Marable 2007, Robnett 2020). Beginning with the Bakke decision of 1978, there were persistent efforts to overturn early efforts to curb the effects of past discrimination with aggressive affirmative action efforts (Okechukwu 2019, Okechukwu 2020).

In California, there were three years of state actions and protests between 1995 and 1997 , including abolition of "racial preferences" by the UC Board of Regents in 1995, a court decision overturning the action, Proposition 209 outlawing affirmative action in 1996, and the ultimate action of the Board of Regents in 1997. Sixteen articles described 21 protest events involving somewhere between 17,000 and 84,000 people, including a few counter-protests. Articles described coalitions between Black, women's, and other liberal-left organizations seeking to preserve affirmative action, several large street protests with planned arrests for civil disobedience, and protests in and around the Board of Regents' meetings. This struggle included an episode at Cal State Northridge in 1996 where Black and other minority students scheduled a debate about affirmative action between Civil Rights activist Joe Hicks and former KKK leader David Duke. Republicans went to court to try to block the event, claiming that it falsely implied that opposition to affirmative action was racist. Besides the debate and lawsuit, there were a Republican counter-protest, anti-Duke counter-protests by Bay Area Black BAMN activists, and counter-counter protests by Black students supporting the debate.

In Florida, Governor Jeb Bush announced a plan to abolish affirmative action in public universities in January 2000. Two state legislators staged a sit-in in his office while other protesters gathered. In the next two months, before the legislature enacted the proposal, there were multiple protests around the state including a large protest at the capitol and bus drivers refusing to work so that instead they could provide transportation for protesters. The sequence involved 11 events covered in 10 news stories and an estimated 15,000 to 25,000 participants. 
Other affirmative action protests received less newswire coverage including a campus protest in Texas in 1997 about a professor defending the previous-year's abolition of affirmative action, a three-day march in Louisiana in 1996 involving 5,000-7,000 people protesting the governor's abolition of affirmative action in state employment, and several smaller protests in other places. There was only vague newswire coverage of protests in Michigan at the time of the 2003 Supreme Court case, although other sources suggest there were many protests about that case.

\section{White Supremacists}

Episodes involving overt White supremacists accounted for $9 \%$ of issue clusters, $8 \%$ of events, and $6 \%$ of articles involving Black protest. These White supremacist groups were very small, and counter-protesters typically greatly outnumbered them. The protests often created situations where counter-protesters confronted police. In Toledo in 2005, for example, Nazis insisted on marching without a permit in a Black neighborhood. Despite refusing to issue a permit, police showed up to protect the Nazis and escort them through the Black neighborhood. Once Black people confronted the police, the Nazis went home, and it turned into a "Black riot" against the police. There was more coverage of White supremacists when they faced apparent violence or militancy by Black opponents. These stories follow a pattern of police minimizing the danger of White supremacists and exaggerating the threat of Black protesters reported in more recent research (Castle 2020, Mian 2020), as well as in research on the mid-1900s FBI (Cunningham 2003).

Most of these events received only one or two news mentions, but a few were more newsworthy. After a brutal and widely publicized hate crime in 1998 in the small town of Jasper, Texas, an announced standoff between a dozen KKK members and 30 Black nationalists including the New Black Panther Party turned into a media circus with hundreds of police, reporters, and bystanders. It was covered in nine articles. Six articles described a similar episode of confrontations between the KKK and the NBPP in 2008-09 around a case originally thought to be an intentional vehicular homicide in Paris, Texas. ${ }^{8}$

\section{Broader Alliances: Workers, Coalitions, Politics}

We cast a wide net and included events that had visible Black participants even if the issue was not Black-centered. We discuss these issues briefly because they point to how Black activists and organizations were involved in the full range of social issues.

\section{Workers}

Black unionists were important parts of the Civil Rights movement between the 1930s and 1960s (Marable 2007, Nichter 2021). We included worker-centered and union events if they included racial discrimination as an issue, involved Black workers or workers in occupations that have a high proportion of Black workers, or involved support from Black organizations or Black activists. This included some borderline cases regarding their relevance for the Black movement, including a big UPS strike. While $9 \%$ of the specific issues we identified involved workers, worker issues were underrepresented in events, participants, and especially news coverage. The only specific issue that received an extensive news coverage (nine articles) was a five-day bus ride between Atlanta, Georgia and Wilmington, Delaware with rallies in cities along the way to protest discriminatory layoffs by Coca-Cola in 2000. Two articles described a 2000 SEIU strike by janitors in Los Angeles that was supported by Jesse Jackson and a follow-up SEIU campaign by security guards supported by the SCLC, which are described in Bloom (2011). 


\section{Elections, Candidates, and Partisanship}

Consistent with other protest event researchers, we exclude ordinary political rallies during elections from our data, but we do capture protests relevant to political issues. Prior to 2008 , the biggest political story relevant to the Black movement was the 2000 presidential election, which included complaints about Florida's permanent disenfranchisement of people convicted of felonies and its having purged voter registration rolls of many Black people who were eligible voters. Among many other groups, Black activists and organizations protested throughout the process of litigation. We identified 17 articles about 21 events in this episode. Protests continued into the 2001 inauguration of George W. Bush, where we counted another four Black-relevant protest events covered by 13 articles. Struggles around voting rights, voting rules, and the electoral college have obviously persisted.

Other pre-Obama political events included Black participation in the anti-war protests at Bush's second inauguration in 2005, in coalitions protesting various issues at the quadrennial presidential nominating conventions of both parties, and in smaller actions in the 1990s against specific political figures, including Newt Gingrich and Clarence Thomas, or in support of President Clinton.

Political events became more overtly racialized after the election of President Obama. ${ }^{9}$ There were several events around claims of racial stereotyping of him, including protests in February 2009 objecting to a political cartoon portraying Obama as a gorilla. Conservative commentators, including Rush Limbaugh and Glenn Beck, called Obama's policies racist, antiWhite "reparations." The newswires printed a few stories about whether racism animated the 2010 Tea Party protests. For the August 2010 anniversary of the March on Washington, Glenn Beck scheduled an anti-Obama rally at the Lincoln Memorial and continued his claims that Obama was racist. This rally provoked counter-protests and gained a great deal of news coverage. Two large rallies in reaction to Beck and in anticipation of the November election were held in October, each described in three newswire articles: the October 2 multi-racial One Nation Rally by a coalition of 300 organizations that included NAACP and the October 30 rally for civility with predominantly White attendees called by humorists Stephen Colbert and Jon Stewart. ${ }^{10}$

\section{Coalitions}

Black activists and organizations participated in events around a wide range of issues including events for and against gay rights, abortion, and other groups such as immigrants or Muslims. We classified the 2000 Million Moms march about gun control, previously discussed, as a coalition event. Another coalition event was the 1996 Stand for Children rally of about 200,000 people against the Clinton welfare reform bill organized by Miriam Edelman, a Black woman who was head of the Children's Defense Fund (Franklin 2014). The religious 1997 Promise Keepers rally of at least 300,000 men had racial reconciliation as a major theme and many Black speakers, although reports said the crowd was overwhelmingly White. This rally was part of a broader engagement of Evangelical Christians with issues of racial reconciliation in the late 1990s (Kendi 2016).

Our newswire stories reported Black-led protests both for and against abortion, as well as Black participation in coalitional pro-and anti-abortion events, but did not discuss intersectional organizing around reproductive rights such as SisterSong, which was founded in this era (Luna 2009, Luna 2016) or the Chicago Abortion Fund, which was transformed from a White- 
dominated to a Black-led organization in the 1990s and 2000s (Daniel and de Leon 2020). Similarly, although there was coverage of Black pro-gay and anti-gay protests, our newswire stories did not cover the growing importance of Black queer people and groups during this time (Fujino and Blake 2020, Ransby 2018).

We found many events relevant to immigrants and immigration but only coded those that mentioned Black participants or issues. In the 1990s, protesters advocated that Haitians specifically and other Black immigrants be treated more fairly, especially in contrast to Cubans. Most of the victims in the big New York police violence episodes of the 1990s were Black immigrants. There were huge protests by immigrants, especially Latinos, in 2006. Newswires covered both inter-ethnic conflict between Blacks and Latinos, as well as attempts to form alliances between Blacks and Latinos and call attention to Black immigrants. Eighteen news stories described 20 fights between Black and Hispanic incarcerated people in California, most in Los Angeles jails in late 2005 to early 2006. Latino organizations received permission from Black organizations to use the name "Immigrant Freedom Ride" for a campaign in which immigrant protesters rode buses from cities around the country to converge in Washington DC and then New York for pro-immigrant rallies. The Black Alliance for Just Immigration was founded in 2006. Zamora and Osuji (2014) discuss the difficulties immigrant rights activists had in reaching out to African Americans.

\section{Other Black-Centered Issues}

Another 100 specific issues (23\% of the total) that were addressed in 229 events $(17 \%$ of the total) and 187 articles (15\% of the total) involved somewhere between 64,000 and 218,000 people (1.4\% to $1.6 \%$ of total participants). Of these "other" issues, $70 \%$ were described in only one article and only seven (7\%) were described in more than four articles. To try to bring some order to this large residual category, we subdivided the issues into those that were campus-based, those that addressed a local place-based issue, those that addressed other Black issues, and those that involved conflicts within Black organizations. Table A2 in the online supplement provides some information about the subcategories within these categories.

Twelve articles covered eight events involving 1,200-2,400 people at Rutgers University in 1995 about the university president saying that Blacks are intellectually inferior-he said he meant the opposite - including sit-in that disrupted a basketball game. Five articles discussed five events in the spring of 2001 in which Black students protested inadequate responses to their receiving death threats at Penn State. Other campus protests addressed ethnic studies, ethnicityfocused dorms, struggles for control over student government, and violence or threats against racial minority students. Although we classified it with “other” issues, Horowitz's 2001 antireparations campaign (discussed above) could have been considered a campus issue.

The biggest "local" issue was post-hurricane New Orleans. Six articles discussed six events in late 2005 and early 2006 about whether residents displaced by the hurricane would be allowed to vote in local elections in 2006, and seven articles discussed four events in 2006-8 about concerns that redevelopment was failing to rebuild Black housing and was making the city whiter. Several scholars have written about the reactions of Black people to the disastrous response to Hurricane Katrina and subsequent organizing efforts in New Orleans (Brand 2018, Camp 2009, Camp 2016, Harris-Perry 2011, Johnson et al. 2010, Woods 2017). Ten clusters addressed issues of community violence in various cities, nine addressed local school issues, 
nine addressed economic issues such as poverty or the treatment of homeless people or business development, and twelve were "other" local.

Ten articles covered eight protests against Sudan for atrocities in Darfur between 2004 and 2009, including Black Congresspeople protesting at the Sudanese embassy and several large rallies with total participation estimated to be between 10,000 and 40,000 people. Seven articles discussed planned protests at 25 television stations in 1996 about the lack of Black Oscar nominees. Other issues included charges of discrimination against consumers, media bias, and discriminatory speech and symbols.

Overall, the newswires occasionally reported events representing the wide diversity of Black collective action, while not covering other similar events recorded in qualitative sources, including protests about police violence in the St. Louis area (Rogers 2015), the successful campaign against a Shintech plant in Convent, Louisiana (Hines 2001), and unsuccessful campaigns in Sumter County, Alabama (Hines 2007) and Mossville, Louisiana (Hines 2015). The obvious implication is that there are many local struggles that are covered in neither the national newswires nor the academic case study literature.

\section{DISCUSSION}

This paper is unapologetically descriptive. We provide a panoramic view of Black protest from 1994 to 2010 as it appeared in mainstream (White) newswires and put it into dialog with qualitative accounts. However, our descriptions do have theoretical implications. We see three crucial stylized facts (Hirschman 2016) to be theorized. First, there is continuity in issues addressed by Black movement activists between the 1990s and the 2020s. Except for the Million Man March and related events, most issue categories addressed by protesters and activists in the 1990 s and the 2000s remain the focus of activists in the 2020s. Second, there have long been multiple strands of Black political ideology that have varied in their relative popularity among Black people over time, and many different issues Black activists have addressed. It is a mistake to focus on only one issue arena or ideological tendency when studying Black collective action. Third, there was no scale shift in the level of protest in the 1990s and 2000s as there was in 2014-16 and again in 2020.

While we are not prepared to offer a theory of the Black movement to explain these stylized facts, we believe much of the data is broadly consistent with many of the tenets of Critical Race Theory (Bell 1995, Bracey 2015, Bracey 2016, Ray et al. 2017b, Watkins Liu 2018). Black attempts to increase Black political power or economic well-being, including goals such as increased education, better housing, and access to jobs, have been met with wide-ranging forms of resistance, both violent and institutional, by the dominant White majority. Writing in the wake of the failure to convict the police who beat Rodney King despite video evidence, Derrick Bell called for "racial realism" that would abandon actions based on the hope of equality and instead find meaning in survival and resistance (Bell 1992). Scholars of the period say, and our data confirm, that the racial realism of this era led to Black energy and mobilization.

Struggles over policing are persistent. Policing maintains racial segregation and suppresses Black “disorder." In many ways, police act as an occupying army towards Black Americans, treating them as a hostile population who must be suppressed to protect the (White) nation. The politically motivated "drug war" of the 1980s and 1990s targeted Black communities, spinning off racially biased patterns of mass incarceration and stop-and-frisk 
policing that put more Black people at risk of harm from over-aggressive social control. Periodically, these fundamental issues burst into mainstream (White) news, and then fade away as the issue attention cycle moves on. Just as in the most recent protest waves, police violence and discrimination in the legal system were major issues in the 1990s and 2000s. The cases of Rodney King, Abner Louima, Amadou Diallo, Timothy Thomas, Sean Bell, and Oscar Grant all attracted extensive media coverage and provoked widespread mainstream discussions about race and policing. Many more cases sparked local protests but did not become major national media stories. Both the persistence of struggles about policing and mainstream news sources' disproportionate coverage of them are consistent with a Critical Race view that treats coercive control of Black people as a core feature of the United States. Other evidence of mainstream media preoccupation with Black people as threats to White security were the major stories about the Freddy's arson/murder and the responses to the Million Youth March in New York, as well as other stories highlighting the perceived dangerousness of the New Black Panther Party and issues of disorder at Black spring break festivals.

A broad Critical Race perspective is also consistent with the longstanding struggle over racialized national identity embodied in the conflicts over Confederate symbols versus memorializing Black struggles including slavery and the CRM. Black activists in the 1990s proactively sought to remove symbols of White domination that had been placed as acts of White resistance to the Civil Rights movement in the 1960s. There were few victories at the time. The Confederate flag was finally removed from the South Carolina capitol in 2015 after a horrific mass murder. Some Confederate statues have been officially removed or toppled via mass direct action since 2014. In 2019, the New York Times published Nikole Hannah-Jones's The 1619 Project, a Black-centric narrative about the founding of the nation. In response, some White activists have redoubled their efforts to reclaim a White supremacist narrative of national unity (Ray and Gibbons 2021). Similarly, campaigns for reparations for slavery were advanced in the 1990s through 2001 and have been reinvigorated recently, each time being met by resistance and diversion. The story of active White resistance to redress for the past via affirmative action has been told by others, and our data show only defensive reactive protests attempting to stop the dismantling of affirmative action. While the dismantling continued, news stories about active attempts to defend affirmative action declined. Also showing continuity with the present were the smattering of KKK and neo-Nazi events that revealed their ongoing presence in the 1990s and 2000s (Berbrier 1998a, Berbrier 1998b, Berbrier 2000, Berbrier 2002, Dobratz and Shanks Meile 1997, Simi and Futrell 2020). Among these we often saw the police defending White supremacists against counter-protesters, a phenomenon that has become even more marked in the current era.

Our data also show Black activists working on a wide variety of issues, most of them ongoing areas of contention. Many of these were local or single-issue campaigns addressing discrimination in some institutional sphere, including complaints about campus racism, job discrimination, or treatment of indigent people. Some sought to reduce intra-community violence or defend local schools from budget cuts. Many were in concert with groups organized around other axes of domination or interest, including labor unions, political groups, and coalitions. Black activism has always addressed a broad agenda involving many issues, and Black activists have often made common cause with other groups. Black unionists were important actors in the Civil Rights era and Black activists in our data are visible in supporting both actions specifically about racial discrimination by employers and broader union organizing campaigns or strikes. 
Like non-Black Americans, Black people showed up on both sides of the 1990s and 2000s struggles over abortion laws, gay rights, and immigration, although mainstream Black Civil Rights organizations and activists generally were for legal abortion, gay rights, and immigrant rights. Black people protested the debacle of the 2000 election and associated racial bias in voting rules and conducted less-covered voter registration drives. Across nearly all these issues, there is still ongoing contention and no final outcomes. Repeatedly, Black activists have sought proactive ground to advance the living conditions for Black and other people, but this rarely becomes a story in the mass media. The Movement for Black Lives in 2016 published an agenda that sought to go beyond policing issues to the broader economic, political, gender, and social structures that affect Black people especially, but also other working-class people and other marginalized groups. It received little mainstream news attention.

The major story from the 1990 s that does not seem to have carried over to the 2020 s or even the 2000s is the rise in Black nationalism reflected in the Million Man March and the mobilizations associated with it. Louis Farrakhan and the Nation of Islam are still around and active and important actors in many Black communities, but they are rarely part of the contemporary national mainstream (White) media conversations. Even in the 1990s, the rise of Black nationalism did not make much of an impression in the newswires beyond coverage of the March itself, although academics commented on it at the time. Did Black cultural nationalism truly decline or is it just invisible to the White gaze? It appears that the election of Barack Obama at least initially inspired an optimism among Black Americans that Obama's own rhetoric cast in assimilationist terms. Taylor (2016) argues that disillusionment with Obama in his second term was one of the factors inspiring the mobilization that led to the Black Lives Matter protest wave. Even in the 1990s, the newswires told us nothing about ongoing threads of Black Power politics (Fujino and Harmachis 2020) or other Black radicals in the Marxian tradition, but there are clear threads of influence of these in the Black Lives Matter movement (Ransby 2018, Taylor 2016). Is there a resurgence of Black nationalism in the resurgence of Black Power ideologies? Are there continuities in these strands of Black politics? Religious groups, both Christian and Muslim, seem less prominent in recent Black movement politics. Have they been replaced by new forms of community?

The Black movement was in abeyance in the 1990s, but it was not demobilized. There was obvious energy and enthusiasm in the wake of the Million Man March and proactive efforts on several fronts. The data show a burst of mobilization around a wide range of issues peaking in 2000 and 2001. These US mobilizations coincided with global mobilizations around racism and slavery reparations. We will never know whether $9 / 11$ cut off a rising protest wave that could have grown to scale shift. Protests rose again in the late 2000s after Hurricane Katrina and in the context of major protest mobilizations by Latino/as around immigration policies. The big New York mobilizations around the killing of Sean Bell in 2006 and 2008 followed the template laid down in the 1990s. The 2007 Jena 6 mobilization was orchestrated online by ColorOfChange.org, presaging the Internet organizing era. The "riots" in Oakland in 2009 and 2010 around the police killing of Oscar Grant followed the first widely publicized case of a police killing recorded by a cellphone camera. Glenn Beck's 2010 anti-Obama rally at the Lincoln Memorial on the anniversary of the March on Washington was part of the larger rhetorical effort to frame Black people and anything that benefits Black people (even if it also benefits Whites) as racist and anti-White. All of these seem like the obvious precursors to the politics and movements of the 2010s and later. 
While there is continuity in the issues and some actors leading Black protests since the 1990s, the Black Lives movement did mark important changes in movement leadership and movement organizations. The Movement for Black Lives is ideologically grounded in Black radical traditions and intersectional analyses that highlight a Black, queer, and feminist lens. Most notable in the 2014-16 protest wave was the high visibility of Black women, especially queer Black women, and the lack of centralized leadership. Organizers Patrisse Cullors, Alicia Garza, and Opal Tometi are most often mentioned for coining the Twitter hashtag \#BlackLivesMatter that became the name of the movement after November 2014 (Freelon, McIlwain and Clark 2016, Ray et al. 2017a, Ray, Brown and Laybourn 2017) and of the organization they founded. Less frequently mentioned in mainstream accounts are DeRay Mckesson and Johnetta "Netta" Elzie, who were prominent for tweeting from Ferguson using the hashtag \#Ferguson in the early months after the killing of Michael Brown, or Charlene Carruthers, who founded BYP100, another major BLM organization, on the day of the 2013 Zimmerman verdict. BYP100 was founded at a convention of the Black Youth Project, which in turn had been created in 2004 by Cathy Cohen. Black Lives Matter Global Network, BYP100, and many organizations formed the broader umbrella organization Movement for Black Lives (M4BL). None of these activists and organizations arose ex nihilo, however; they came from community organizing and leadership development projects that had been going on for years (Oliver 2020, Ransby 2018, Rogers 2015, Taylor 2016, Weddington 2018). The protests built on the ongoing local movement centers (Morris 1984) present in most cities. They had been preceded by the Million Hoodies protests in 2012 around the killing of Trayvon Martin by George Zimmerman (Ehrlich 2013). Much of their ideology can be seen as building on work begun by Black women and men, both queer and straight, in the late 1990s by INCITE!, Critical Resistance, and the Black Radical Congress. These M4BL activists kept working and forming alliances and provided organizational underpinnings of the 2020 protests after the police murder of George Floyd.

Our research cannot address the question of why there was a scale shift in protests in 2015-16 and 2020 but not in the late $20^{\text {th }}$ century. Why did the "big" cases of the 1990 s and 2000s fail to provoke a scale shift, despite extensive mobilization and the national media attention paid to them? Protests in the earlier decades attracted fewer White allies. There were some calls for national hearings and nationwide protests about police violence and discrimination in general in the wake of the New York mobilization around the Diallo case, as well as the studies of racial profiling on the New Jersey turnpike, which never took off. There was a shortterm spate of spin-off protests and "riots" after the 1992 not guilty verdict for the police who beat Rodney King. There was no similar pattern of diffusing protests or riots around the Cincinnati 2001 or Oakland 2009-2010, despite media attention to them. Why not? Some of the answers must lie in the structures of the news media, and others in the broader political context. Are there other factors affecting Black mobilization at different times? Or factors that affect the attention of Whites and their willingness to join protests?

Most American school children are taught the myth that the Civil Rights movement started when a tired, old, and apolitical Rosa Parks was the first person to refuse to give up her seat on a segregated bus and ended when Dr. King explained to everybody that they should ignore the color of people's skin. The myth ignores Rosa Parks's own history as an NAACP activist and organizer, the broader movement and resistance that existed before and after that moment, the diversity of organizations and ideologies in the 1960s, and the violence of the 
struggle. Many writers, including even some academics, have deployed a new myth that the protests of 2014-16 were started by a hashtag and treat Black Lives Matter protests as entirely new and disconnected from the past. Some writers about the 2020 protests after the murder of George Floyd seemed to not even remember 2014-16. Many popular accounts of anti-police protests seem confused about why Confederate statues were toppled as part of those protests; few mention the broader proactive agendas advanced by the Movement for Black Lives. Almost nobody mentions events from the end of the $20^{\text {th }}$ century.

New Black leaders, tactics, slogans, and organizations arise in each new generation, even as they are continuous with and draw on the movements of the past. The Black movement is much broader, more diverse, and more grounded in specific communities than the impression provided in mainstream media or studies solely using Twitter data. The Black Lives Movement arose from decades of struggle after the Civil Rights movement when the legitimacy of Black issues was undermined by colorblind racism and Black leaders' attempts to shift the scale of protest and gain proactive purchase were largely thwarted. Organizations building on the momentum of the 1990s and founded around ideas of intersectionality, racial realism, and prison abolitionism and mobilizations of the late 2000s fed into the renewed movement energy of the 2010s and after. Attending to the Black movement at the turn-of-millennium strengthens understanding of the present as well as of the past. 


\section{FIGURES AND TABLES}

Figure 1: African American actors and issues vs other issues in the Dynamics of Collective Action dataset

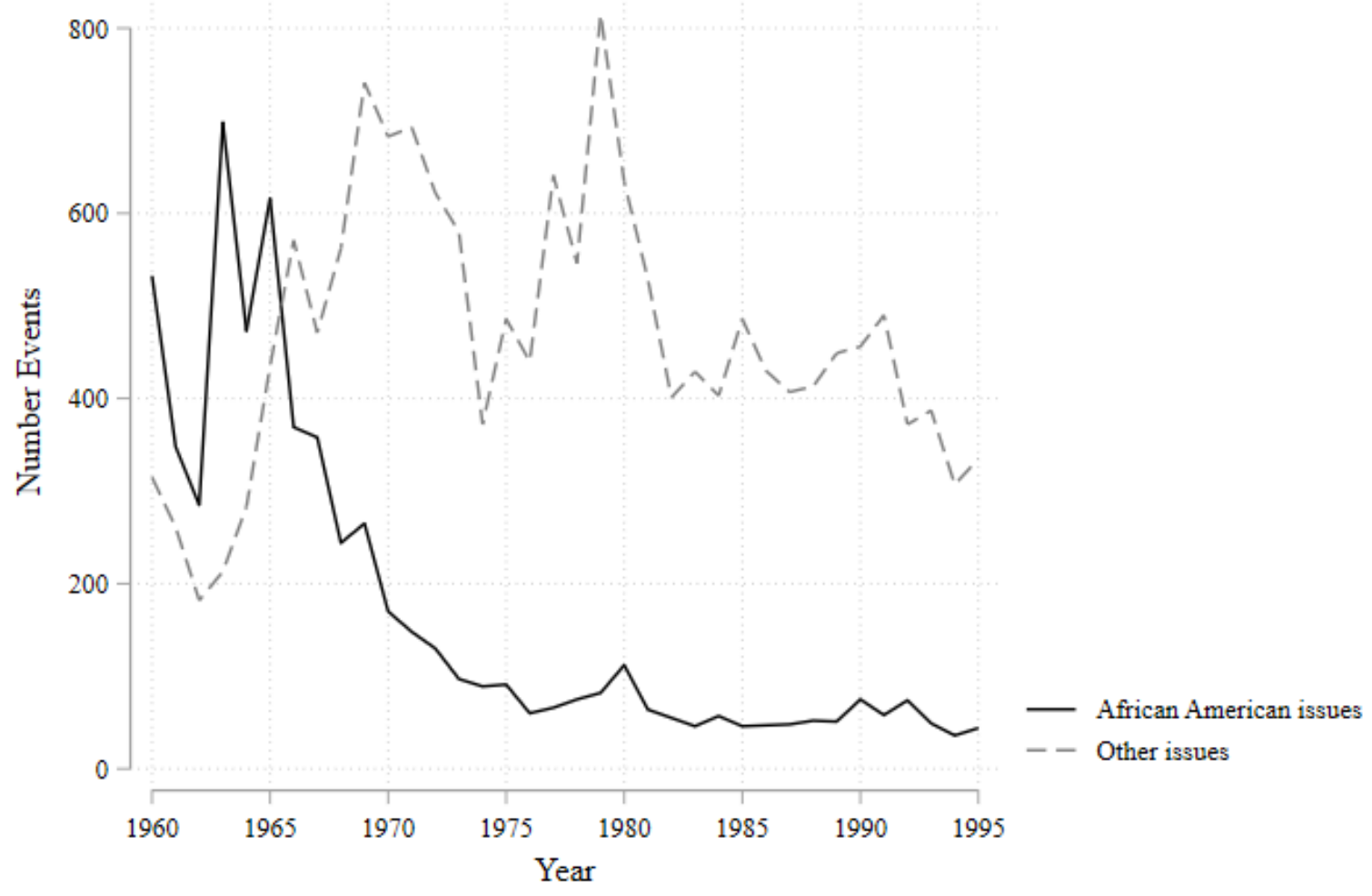


Figure 2 Number of Black protest events, articles, and participants
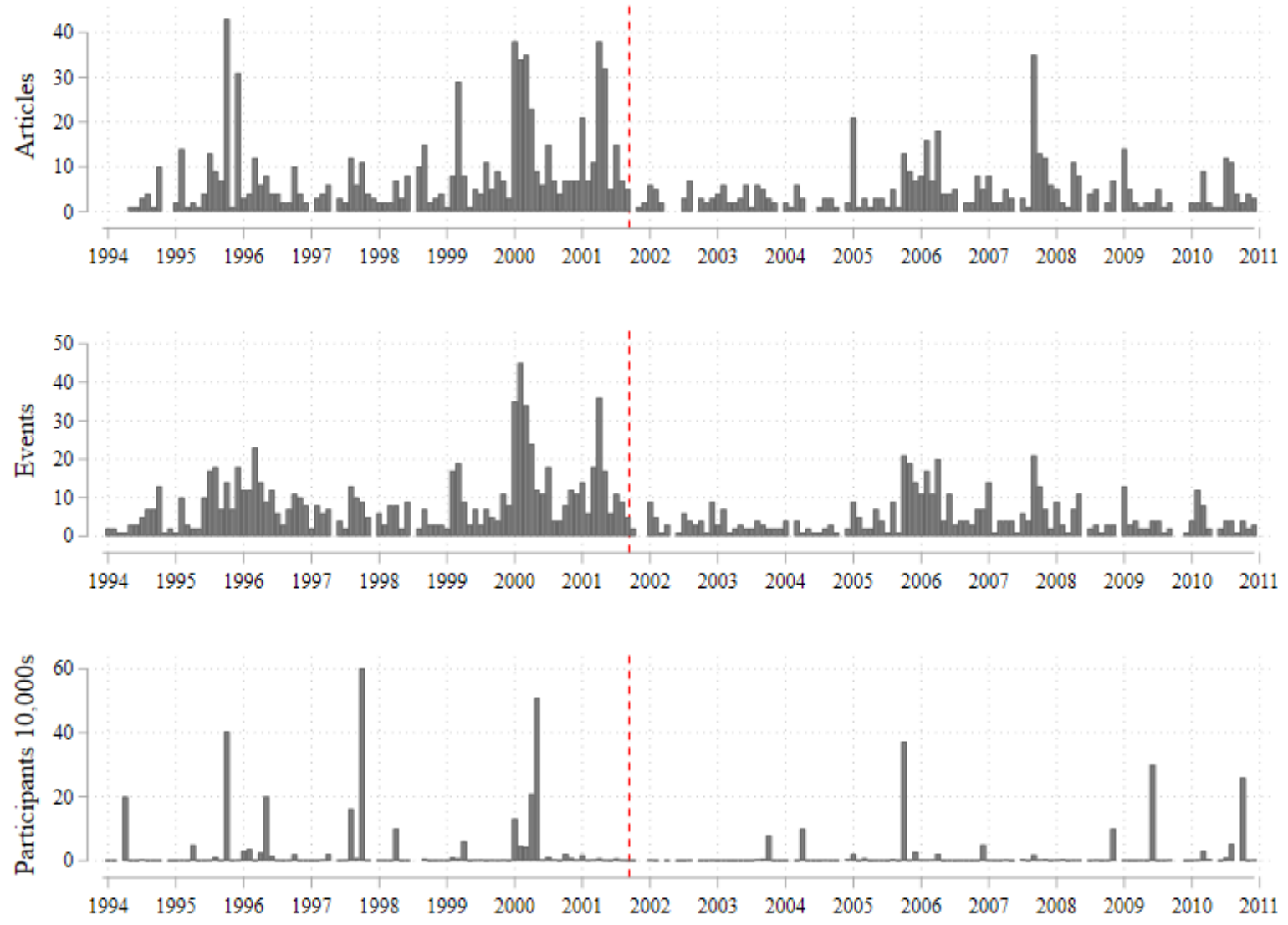
Figure 3 Protest events with Black issues or actors in DCA and BPP

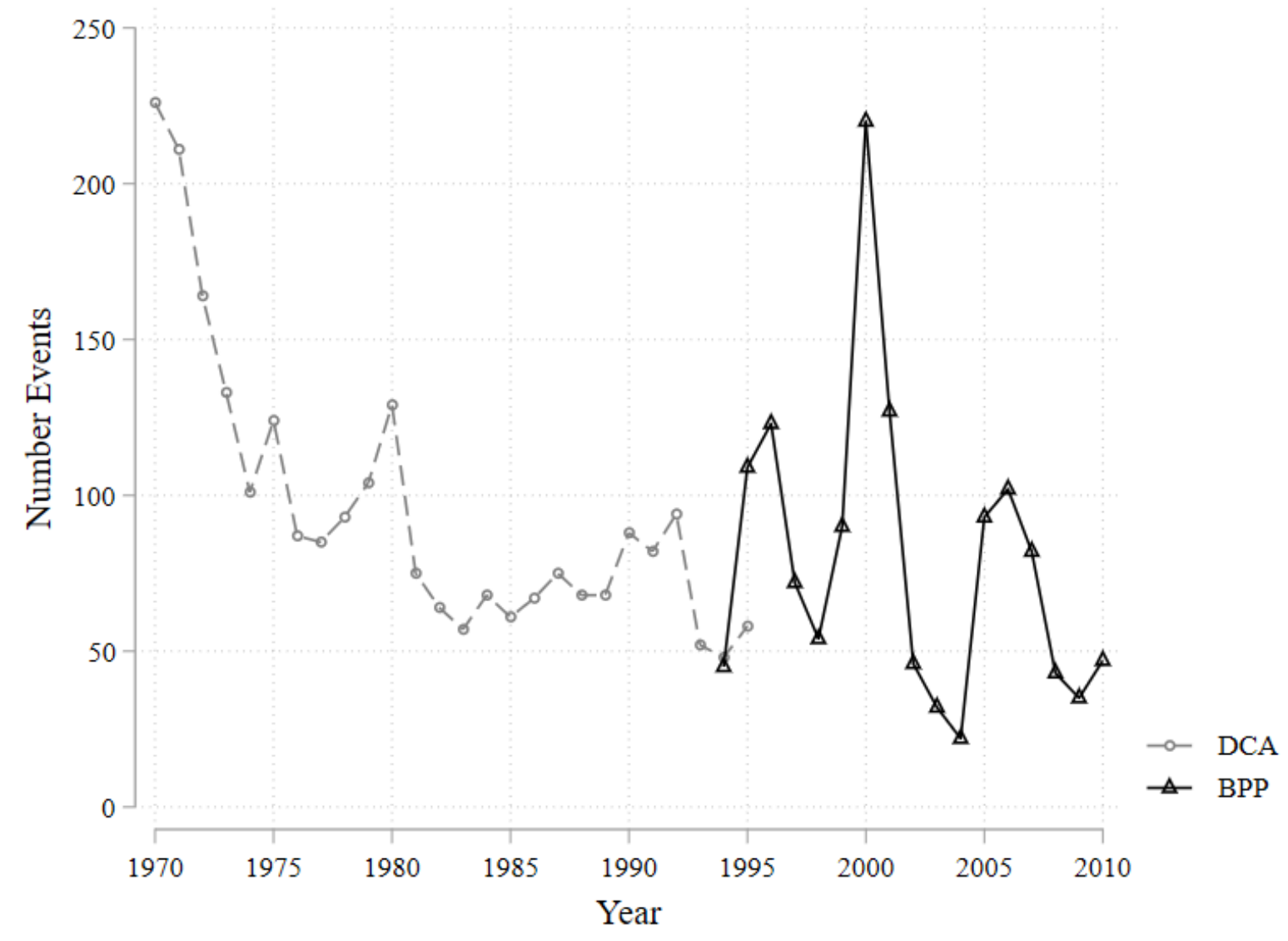


Figure 4 Issue mix for clusters, events, articles, participants

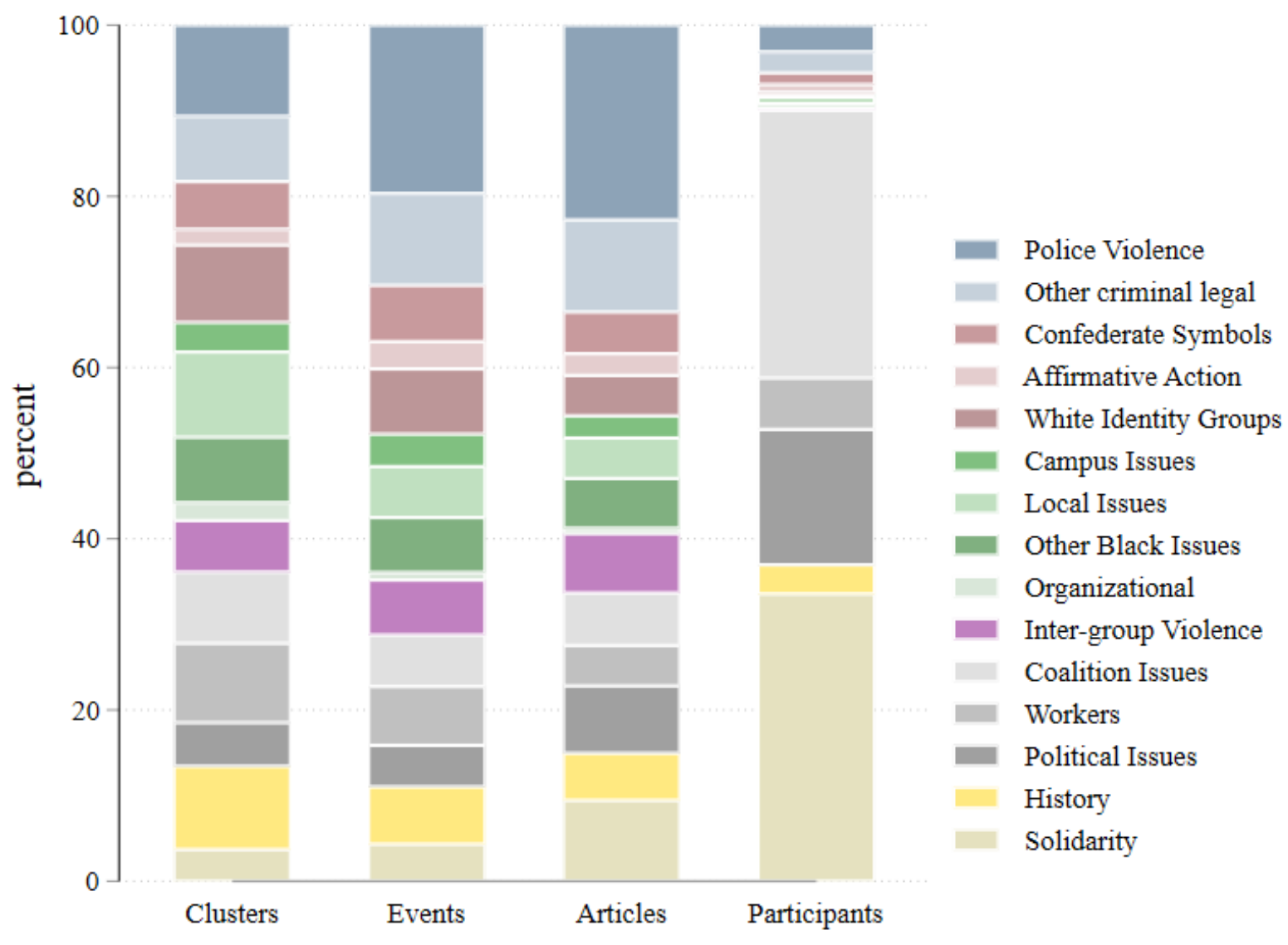


Table 1 Number of events by issue groups and event types

\begin{tabular}{lrrrr}
\hline & \multicolumn{4}{c}{ Event Type } \\
& Black & Anti-Black & Other & Total \\
\hline $\begin{array}{l}\text { Issue Groups } \\
\text { (Criminal Legal) }\end{array}$ & & & & \\
$\quad$ Police Violence & 246 & 13 & 5 & 264 \\
$\quad$ Other criminal legal & 114 & 25 & 5 & 144 \\
(White Issues) & & & & \\
$\quad$ Confederate Symbols & 58 & 29 & 1 & 88 \\
Affirmative Action & 39 & 3 & 1 & 43 \\
White Identity Groups & 58 & 42 & 2 & 102 \\
(Black issues) & & & & \\
$\quad$ Campus Issues & 40 & 10 & 1 & 51 \\
$\quad$ Local Issues & 70 & 5 & 5 & 80 \\
$\quad$ Other Black Issues & 74 & 10 & 2 & 86 \\
$\quad$ Organizational & 12 & 0 & 0 & 12 \\
Inter-group Violence & 74 & 10 & 2 & 86 \\
(Other issues) & & & & \\
$\quad$ Coalition Issues (e.g., welfare, immigration) & 59 & 0 & 22 & 81 \\
$\quad$ Workers (unions + discrimination) & 68 & 2 & 22 & 92 \\
$\quad$ Political Issues & 51 & 6 & 8 & 65 \\
(Black Identity) & & & & \\
$\quad$ History (commemorations, truth-telling) & 87 & 1 & 2 & 90 \\
$\quad$ Solidarity & 57 & 1 & 0 & 58 \\
Total & 1107 & 157 & 78 & 1342 \\
\hline
\end{tabular}


Table 2 Percent of event mentions, events, articles, clusters including name

\begin{tabular}{|c|c|c|c|c|}
\hline & $\begin{array}{r}\% \text { event } \\
\text { mentions }\end{array}$ & $\begin{array}{r}\% \\
\text { events }\end{array}$ & $\begin{array}{r}\% \\
\text { articles }\end{array}$ & $\begin{array}{r}\% \\
\text { clusters }\end{array}$ \\
\hline \multicolumn{5}{|l|}{ (Civil Rights) } \\
\hline NAACP & 18 & 18 & 16 & 17 \\
\hline Al Sharpton & 21 & 17 & 20 & 11 \\
\hline Jesse Jackson & 13 & 12 & 13 & 10 \\
\hline NAACP or Sharpton or Jackson & 45 & 41 & 41 & 33 \\
\hline $\mathrm{SCLC}$ & 3 & 3 & 3 & 3 \\
\hline Martin Luther King III & 3 & 2 & 3 & 1 \\
\hline Coretta Scott King & 2 & 2 & 1 & 2 \\
\hline Rosa Parks & 2 & 3 & 2 & 2 \\
\hline Rainbow/PUSH (no Jackson) & 1 & 1 & 0 & 1 \\
\hline Ben Chavis (no NAACP) & 1 & 1 & 1 & 0 \\
\hline Kweisi Mfume (no NAACP) & 0 & 0 & 0 & 0 \\
\hline \multicolumn{5}{|l|}{ (NOI \& NBPP) } \\
\hline Louis Farrakhan & 7 & 5 & 7 & 5 \\
\hline Khalid Abdul Muhammad & 3 & 1 & 3 & 1 \\
\hline Malcolm Zulu Shabazz & 1 & 1 & 1 & 1 \\
\hline Nation of Islam (no Farrakhan, Muhammad, or & & & & \\
\hline Shabazz) & 2 & 3 & 2 & 2 \\
\hline New Black Panthers (no Muhammad or & & & & \\
\hline Shabazz) & 2 & 2 & 2 & 1 \\
\hline \multicolumn{5}{|l|}{ (Non-Black Ally Groups) } \\
\hline Civil Liberties Union (ACLU \& affiliates) & 4 & 3 & 4 & 3 \\
\hline AFL-CIO & 1 & 2 & 1 & 2 \\
\hline National Organization for Women & 1 & 1 & 1 & 1 \\
\hline Amnesty International & 0 & 1 & 0 & 0 \\
\hline Anti-Racist Action & 0 & 0 & 0 & 0 \\
\hline \multicolumn{5}{|l|}{ (Totals) } \\
\hline Any of the listed names or groups & 59 & 55 & 55 & 47 \\
\hline None of the listed names or groups & 41 & 45 & 45 & 53 \\
\hline Total & 100 & 100 & 100 & 100 \\
\hline Number Cases & 2674 & 1342 & 1210 & 432 \\
\hline
\end{tabular}




\section{REFERENCES}

Abu-Lughod, Janet L. 2007. Race, Space, and Riots in Chicago, New York and Los Angeles. New York: Oxford University Press.

Amenta, Edwin, Neal Caren, Sheera Joy Olasky and James E. Stobaugh. 2009. "All the Movements Fit to Print: Who, What, When, Where, and Why Smo Families Appeared in the New York Times in the Twentieth Century." American Sociological Review 74(4):636-56.

Baggetta, Matthew and Daniel J Myers. 2021. "Interpreting Unrest: How Violence Changes Public Opinions About Social Movements." Social Movement Studies:1-24.

Beckett, Katherine. 1997. Making Crime Pay : Law and Order in Contemporary American Politics. New York: Oxford University Press.

Bell, Derrick. 1992. "Racial Realism." Connecticut Law Review 24(2 Winter):363-80.

Bell, Derrick A. 1980. "Brown V. Board of Education and the Interest-Convergence Dilemma." Harvard Law Review 93(3):518-33. doi: 10.2307/1340546.

Bell, Derrick A. . 1995. "Who's Afraid of Critical Race Theory?". University of Illinois Law Review 1995(4):893-910.

Bell, Joyce M. 2014. The Black Power Movement and American Social Work. New York: Columbia University Press.

Berbrier, Mitch. 1998a. "White Supremacists and the (Pan-)Ethnic Imperative: On "EuropeanAmericans" and "White Student Unions"." Sociological Inquiry 68(4):498-516. doi: 10.1111/j.1475-682X.1998.tb00482.x.

Berbrier, Mitch. 1998b. "“Half the Battle": Cultural Resonance, Framing Processes, and Ethnic Affectations in Contemporary White Separatist Rhetoric*." Social Problems 45(4):431-50. doi: $10.2307 / 3097206$.

Berbrier, Mitch. 2000. "The Victim Ideology of White Supremacists and White Separatists in the United States." Sociological Focus 33(2):175-91. doi: 10.1080/00380237.2000.10571164.

Berbrier, Mitch. 2002. "Making Minorities: Cultural Space, Stigma Transformation Frames, and the Categorical Status Claims of Deaf, Gay, and White Supremacist Activists in Late Twentieth Century America." Sociological Forum 17(4):553-91.

Bloom, Joshua. 2011. "9. Ally to Win: Black Community Leaders and Seiu's La Security Unionization Campaign." Pp. 167-90 in Working for Justice: Cornell University Press.

Bloom, Joshua and Waldo E. Martin. 2013. Black against Empire: The History and Politics of the Black Panther Party. Berkeley: University of California Press.

Bracey, Glenn E. 2015. "Toward a Critical Race Theory of State." Critical Sociology (Sage Publications, Ltd.) 41(3):553-72. doi: 10.1177/0896920513504600.

Bracey, Glenn E. 2016. "Black Movements Need Black Theorizing: Exposing Implicit Whiteness in Political Process Theory." Sociological Focus 49(1):11-27. doi: 10.1080/00380237.2015.1067569.

Brand, Anna Livia. 2018. "The Duality of Space: The Built World of Du Bois' Double-Consciousness." Environment and Planning D: Society and Space 36(1):3-22. doi: 10.1177/0263775817738782.

Brasted, Monica. 2005. "Protest in the Media." Peace Review 17(4):383-88. doi: 10.1080/10402650500374645.

Brewer, Rose M. 2003. "Black Radical Theory and Practice: Gender, Race, and Class." Socialism and Democracy 17(1):109-22. doi: 10.1080/08854300308428344.

Bruyneel, Kevin. 2014. "The King's Body: The Martin Luther King Jr. Memorial and the Politics of Collective Memory." History and Memory 26(1):75-108. doi: 10.2979/histmemo.26.1.75.

Burke, Jordan C. 2020. "White Discipline, Black Rebellion: A History of American Race Riots from Emancipation to the War on Drugs." Ph.D., University of New Hampshire, Ann Arbor. Retrieved from ProQuest Dissertations \& Theses Global, 28262213. 
Button, James W. 1978. Black Violence : Political Impact of the 1960s Riots. Princeton, N.J.: Princeton University Press.

Camp, Jordan T. 2009. ""We Know This Place": Neoliberal Racial Regimes and the Katrina Circumstance." American Quarterly 61(3):693-717.

Camp, Jordan T. 2016. Incarcerating the Crisis : Freedom Struggles and the Rise of the Neoliberal State: Oakland, California : University of California Press.

Campbell, Shannon, Phil Chidester, Jason Royer and Jamel Bell. 2004. "Remote Control: How Mass Media Delegitimize Rioting as Social Protest." Race, Gender \& Class 11(1):158.

Castle, Taimi. 2020. "“Cops and the Klan": Police Disavowal of Risk and Minimization of Threat from the Far-Right." Critical Criminology 29:215-35. doi: 10.1007/s10612-020-09493-6.

Cha-Jua, SundiataKeita and Clarence Lang. 2007. "The "Long Movement" as Vampire: Temporal and Spatial Fallacies in Recent Black Freedom Studies." The Journal of African American History 92(2):265-88. doi: 10.1086/JAAHv92n2p265.

Chambliss, William J. 1995. "Crime Control and Ethnic Minorities: Legitimizing Racial Oppression by Creating Moral Panics." Pp. 235-58 in Ethnicity, Race, and Crime: Perspectives across Time and Place, Suny Series in New Directions in Crime and Justice Studies, edited by D. F. Hawkins. Albany: State $U$ of New York Press.

Ciccariello-Maher, George. 2009a. "Fired up, Can't Take It No More': From Oakland to Santa Rita, the Struggle Continues." CounterPunch. Retrieved 2020 (https://www.counterpunch.org/2009/02/03/quot-fired-up-can-t-take-itno-more-quot/).

Ciccariello-Maher, George. 2009b. "Oakland Is Closed!' Arrest and Containment Fail to Blunt Anger in the Streets." CounterPunch. (https://www.counterpunch.org/2009/01/16/quot-oakland-isclosed-quot/).

Ciccariello-Maher, George. 2009c. "Oakland's Not for Burning? Popular Fury at yet Another Police Murder." CounterPunch. (https://www.counterpunch.org/2009/01/09/oakland-s-not-forburning/).

Ciccariello-Maher, George. 2010. "Oakland's Verdict." CounterPunch. (https://www.counterpunch.org/2010/07/12/oakland-s-verdict/).

Cossack, Roger. 1996. "What You See Is Not Always What You Get: Thoughts on the O.J. Trial and the Camera." John Marshall Journal of Computer and Information Law 14(3):555-62.

Cullen, Pauline and Clara Fischer. 2014. "Conceptualising Generational Dynamics in Feminist Movements: Political Generations, Waves and Affective Economies." Sociology Compass 8(3):282-93. doi: https://doi.org/10.1111/soc4.12131.

Cunningham, David. 2003. "Understanding State Responses to Left-Versus Right -Wing Threats." Social Science History 27(3):327-70.

Daniel, Meghan and Cedric de Leon. 2020. "Leadership Succession in Intersectional Mobilization: An Analysis of the Chicago Abortion Fund, 1985-2015*." Mobilization: An International Quarterly 25(4):461-74. doi: 10.17813/1086-671x-22-4-461.

Davis, Angela Y. 2016. Freedom Is a Constant Struggle: Ferguson, Palestine, and the Foundations of a Movement: Haymarket Books.

Dobratz, Betty A. and Stephanie Shanks Meile. 1997. 'White Power, White Pride!' : The White Separatist Movement in the United States: New York : Twayne Publishers ; London : Prentice Hall International.

Ehrlich, Brenna. 2013, "Million Hoodies for Trayvon Martin Founder: The Fight Isn't Over. Daniel Maree Urges Celebs and Supporters to Keep Fighting for Justice.": MTV News.

(http://www.mtv.com/news/1710634/trayvon-martin-million-hoodies-org/). 
Felber, Garrett. 2020. Those Who Know Don't Say : The Nation of Islam, the Black Freedom Movement, and the Carceral State: Chapel Hill : University of North Carolina Press.

Fleming, Crystal M. and Aldon Morris. 2015. "Theorizing Ethnic and Racial Movements in the Global Age: Lessons from the Civil Rights Movement." Sociology of Race and Ethnicity 1(1):105-26.

Fletcher, Bill, Jr. and Jamala Rogers. 2014. "No One Said That It Would Be Easy." Black Scholar 44(1):86112. doi: 10.5816/blackscholar.44.1.0086.

Francis, Megan Ming and Leah Wright-Rigueur. 2021. "Black Lives Matter in Historical Perspective." Annual Review of Law and Social Science 17(1):441-58. doi: 10.1146/annurev-lawsocsci-122120100052.

Franklin, Sekou M. 2014. After the Rebellion : Black Youth, Social Movement Activism, and the Post-Civil Rights Generation: New York : New York University Press.

Franzosi, Roberto. 1999. "The Return of the Actor. Interaction Networks among Social Actors During Periods of High Mobilization (Italy, 1919-1922)." Mobilization 4(2):131-49.

Freelon, Deen, Charlton D Mcllwain and Meredith D Clark. 2016. "Beyond the Hashtags:\# Ferguson,\# Blacklivesmatter, and the Online Struggle for Offline Justice." SSRN Social Science Research Network https://ssrn.com/abstract=2747066.

Fujino, Diane and Matef Harmachis, eds. 2020. Black Power Afterlives : The Enduring Significance of the Black Panther Party. Chicago, IL: Haymarket Books.

Fujino, Diane C. and Felice Blake. 2020. "15. Black Queer Feminism and the Movement for Black Lives in the South: An Interview with Mary Hooks of Song." in Black Power Afterlives : The Enduring Significance of the Black Panther Party, edited by D. Fujino and M. Harmachis. Chicago, IL: Haymarket Books.

Goldberg, David Theo. 2021, "The War on Critical Race Theory" Boston Review. (https://bostonreview.net/race-politics/david-theo-goldberg-war-critical-race-theory).

Grabe, Maria Elizabeth. 2000. "Narratives of Guilt: Television News Magazine Coverage of the O. J. Simpson Criminal Trial." Howard Journal of Communications 11(1):35-48. doi: 10.1080/106461700246706.

Harris-Perry, Melissa V. 2011. Sister Citizen: Shame, Stereotypes, and Black Women in America: Yale University Press.

Henderson, Kyshia, Samuel Powers, Michele Claibourn, Jazmin L. Brown-lannuzzi and Sophie Trawalter. 2021. "Confederate Monuments and the History of Lynching in the American South: An Empirical Examination." Proceedings of the National Academy of Sciences 118(42):e2103519118. doi: 10.1073/pnas.2103519118.

Hines, Revathi. 2007. "Race, Environmental Justice, and Interest Group Mobilizations: Hazardous Waste and the Case of Sumter County, Alabama." Western Journal of Black Studies 31:50-57.

Hines, Revathi I. 2001. "African Americans' Struggle for Environmental Justice and the Case of the Shintech Plant: Lessons Learned from a War Waged." Journal of Black Studies 31(6):777-89.

Hines, Revathi I. 2015. "The Price of Pollution: The Struggle for Environmental Justice in Mossville, Louisiana." Western Journal of Black Studies 39(3):198-208.

Hinton, Elizabeth Kai author. 2021. America on Fire : The Untold History of Police Violence and Black Rebellion since the 1960s: First edition. New York, NY : Liveright Publishing Corporation, a division of W. W. Norton \& Company, [2021].

Hirschman, Daniel. 2016. "Stylized Facts in the Social Sciences." Sociological Science 3:604-26. doi: 10.15195/v3.a26.

Hogan, Wesley. 2001. "Cincinnati: Race in the Closed City.(Issues)." Social Policy 32(2):49-55. 
Hood, Ashton. 2020. "A Candid Discussion About Social Justice: Iris Roley, the Black United F United Front, and the Hist Ont, and the History of Cincinnati' $Y$ of Cincinnati's Collabor S Collaborative Agreement." Freedom Center Journal 2019(1 Article 9).

Jackson, Sarah J. 2021. "Making \#Blacklivesmatter in the Shadow of Selma: Collective Memory and Racial Justice Activism in U.S. News." Communication, Culture and Critique 14(3):385-404. doi: 10.1093/ccc/tcab007.

Jenkins, J. Craig, David Jacobs and Jon Agnone. 2003. "Political Opportunities and African-American Protest, 1948--1997." American Journal of Sociology 109(2):277-303.

Jennings, James. 2000. The Politics of Black Empowerment the Transformation of Black Activism in Urban America: Detroit : Wayne State University Press, c1992.

Johnson, Cedric. 2007. Revolutionaries to Race Leaders Black Power and the Making of African American Politics: Minneapolis : University of Minnesota Press, c2007.

Johnson, Kirk A., John Sonnett, Mark K. Dolan, Randi Reppen and Laura Johnson. 2010. "Interjournalistic Discourse About African Americans in Television News Coverage of Hurricane Katrina." Discourse \& Communication 4(3):243-61. doi: 10.1177/1750481310373214.

Kelley, Blair Murphy. 2010. "Right to Ride : Streetcar Boycotts and African American Citizenship in the Era of Plessy V. Ferguson." Chapel Hill: The University of North Carolina Press,. Retrieved.

(HeinOnline UNC Press Law Publications

https://www.heinonline.org/HOL/Page?handle=hein.usreports/rtrds0001\&id=1\&size=2\&collecti on=uncpress\&index=uncpress).

Kendi, Ibram X. author. 2016. Stamped from the Beginning: The Definitive History of Racist Ideas in America: New York : Nation Books.

Kilgo, Danielle K. and Rachel R. Mourão. 2021. "Protest Coverage Matters: How Media Framing and Visual Communication Affects Support for Black Civil Rights Protests." Mass Communication and Society 24(4):576-96. doi: 10.1080/15205436.2021.1884724.

Kriesi, Hanspeter, Swen Hutter and Abel Bojar. 2019. "Contentious Episode Analysis." Mobilization 24(3):251-73.

Lachlan, Kenneth, J Pete Blair, Paul D Skalski, David Westerman and Patric R Spence. 2007. "Media Coverage of the Cincinnati Riots and Implications for Law Enforcement Public Relations." Police Forum 16:12-23.

Lawson, Steven F. 2014. Running for Freedom : Civil Rights and Black Politics in America since 1941. Hoboken, UNITED STATES: John Wiley \& Sons, Incorporated.

Layne, Asha. 2021. "It's Not Just Black and White: How Black Immigrants Continue to Influence the Fight against Police Violence." Journal of Liberal Arts and Humanities 2(6):1-7. doi: 10.48150/jlah.v2no6.2021.a1.

Lee, Jennifer. 2002. "From Civil Relations to Racial Conflict: Merchant-Customer Interactions in Urban America." American Sociological Review 67(1):77-98.

Lu, Todd Jianjin. 2020. "Recent Anti-Police Brutality Protests since George Floyd's Death Are Far Larger Than Previous Black Lives Matter Protest Waves." Race, Politics, Justice.

(https://www.ssc.wisc.edu/soc/racepoliticsjustice/2020/06/17/recent-anti-police-brutalityprotests-since-george-floyds-death-are-far-larger-than-previous-black-lives-matter-protestwaves/).

Luna, Zakiya. 2009. "From Rights to Justice: Women of Color Changing the Face of Us Reproductive Rights Organizing." Societies Without Borders 4(3):343-65. doi:

10.1163/187188609X12492771031618.

Luna, Zakiya. 2016. "“Truly a Women of Color Organization”." Gender \& Society 30(5):769-90. doi: $10.1177 / 0891243216649929$. 
MacDonald, John, Robert J Stokes, Greg Ridgeway and K Jack Riley. 2007. "Race, Neighbourhood Context and Perceptions of Injustice by the Police in Cincinnati." Urban Studies 44(13):2567-85.

Manchanda, Nivi and Chris Rossdale. 2021. "Resisting Racial Militarism: War, Policing and the Black Panther Party." Security Dialogue 52(6):473-92. doi: 10.1177/0967010621997220.

Marable, Manning. 2007. Race, Reform, and Rebellion : The Second Reconstruction and Beyond in Black America, 1945-2006. Jackson: University Press of Mississippi.

Martin, Andrew W., Patrick Rafail and John D. McCarthy. 2017. "What a Story?". Social Forces 96(2):779802. doi: $10.1093 / \mathrm{sf} / \mathrm{sox} 057$.

McAdam, Doug. 1982. Political Process and the Development of Black Insurgency, 1930-1970. Chicago: University of Chicago Press.

McAdam, Doug. 1983. "Tactical Innovation and the Pace of Insurgency." American Sociological Review 48(6):735-54.

McAdam, Doug, Sidney Tarrow and Charles Tilly. 2001. Dynamics of Contention. New York: Cambridge University Press.

McAdam, Doug, Robert J. Sampson, Simon Weffer and Heather Maclndoe. 2005. "'There Will Be Fighting in the Streets": The Distorting Lens of Social Movement Theory." Mobilization: An International Journal 10(1):1-18.

McDaniels-Wilson, Cathy, Judson L Jeffries and James N Upton. 2012. "White Racial Consciousness in One Midwestern City: The Case of Cincinnati, Ohio." Black Diaspora Review 3(1):24-43.

McKersie, Robert B. 2021. "The 1960s Civil Rights Movement and Black Lives Matter: Social Protest from a Negotiation Perspective." Negotiation Journal 37(3):301-23. doi: https://doi.org/10.1111/nejo.12367.

Messer, Chris M., Thomas E. Shriver and Krystal K. Beamon. 2018. "Official Frames and the Tulsa Race Riot of 1921: The Struggle for Reparations." Sociology of Race and Ethnicity 4(3):386-99. doi: $10.1177 / 2332649217742414$.

Mian, Zahra N. 2020. "'Black Identity Extremist" or Black Dissident?: How United States V. Daniels Illustrates Fbi Criminalization of Black Dissent of Law Enforcement, from Cointelpro to Black Lives Matter." Rutgers Race and the Law Review 21(1):53-92.

Morris, Aldon. 1984. The Origins of the Civil Rights Movement: Black Communities Organizing for Change. New York: Free Press.

Musgrove, George Derek. 2012. Rumor, Repression, and Racial Politics : How the Harassment of Black Elected Officials Shaped Post-Civil Rights America: Athens : University of Georgia Press.

Musgrove, George Derek. 2019. "“There Is No New Black Panther Party": The Panther-Like Formations and the Black Power Resurgence of the 1990s." The Journal of African American History 104(4):619-56. doi: 10.1086/705022.

Nelson, Laura K. 2021. "Cycles of Conflict, a Century of Continuity: The Impact of Persistent Place-Based Political Logics on Social Movement Strategy." American Journal of Sociology 127(1):1-59. doi: $10.1086 / 714915$.

New York Times. 1986. "Reagan Quotes King Speech in Opposing Minority Quotas." Pp. 20 in New York Times. New York: New York Times.

Nichter, Matthew F. 2014. "Rethinking the Origins of the Civil Rights Movement: Radicals, Repression, and the Black Freedom Struggle." Ph.D., The University of Wisconsin - Madison, Ann Arbor. Retrieved from Dissertations \& Theses @ CIC Institutions; Dissertations \& Theses @ University of Wisconsin at Madison; Ethnic NewsWatch; ProQuest Dissertations \& Theses Global, 3668989.

Nichter, Matthew F. 2021. "“Did Emmett Till Die in Vain? Organized Labor Says No!": The United Packinghouse Workers and Civil Rights Unionism in the Mid-1950s." Labor 18(2):8-40. doi: 10.1215/15476715-8849556. 
Nummi, Jozie, Carly Jennings and Joe Feagin. 2019. "\#Blacklivesmatter: Innovative Black Resistance." Sociological Forum 34:1042-64. doi: 10.1111/socf.12540.

Okechukwu, Amaka. 2019. To Fulfill These Rights : Political Struggle over Affirmative Action and Open Admissions: New York : Columbia University Press.

Okechukwu, Amaka. 2020. "Amaka Okechukwu on the Path to Affirmative Action in Higher Education." Columbia University Press Blog. (https://www.cupblog.org/2020/02/12/amaka-okechukwu-onthe-path-to-affirmative-action-in-higher-education/).

Oliver, Pamela. 2020. "Resisting Repression: The Black Lives Movement in Context." Pp. 63-88 in Racialized Protest and the State: Resistance and Repression in a Divided America, edited by $\mathrm{H}$. Johnston and P. Oliver. Oxford UK and New York NY: Routledge.

Oliver, Pamela E. and Daniel J. Myers. 1999. "How Events Enter the Public Sphere: Conflict, Location, and Sponsorship in Local Newspaper Coverage of Public Events." American Journal of Sociology 105(1):38-87.

Oliver, Pamela E. and Gregory M. Maney. 2000. "Political Processes and Local Newspaper Coverage of Protest Events: From Selection Bias to Triadic Interactions." American Journal of Sociology 106(2):463-505.

Oliver, Pamela E., Alex Hanna and Chaeyoon Lim. 2021. "Constructing Theory-Informed Relational and Verifiable Protest Event Data." SocArXiv https://osf.io/preprints/socarxiv/spzgx/.

Rafail, Patrick. 2015. "Policy Spillover and the Policing of Protest in New York City, 1960-2006." Policing \& Society 25(5):463-83. doi: 10.1080/10439463.2013.878344.

Rafail, Patrick. 2018. "Protest in the City: Urban Spatial Restructuring and Dissent in New York, 19602006." Urban Studies (Sage Publications, Ltd.) 55(1):244-60.

Randolph, Antonia, Victor Erik Ray, Megan Underhill and David Luke. 2019. "Response to Weddington: More Lessons from Afro-Pessimism." Sociology of Race and Ethnicity 5(2):289-93. doi: 10.1177/2332649218807732.

Ransby, Barbara. 2018. Making All Black Lives Matter : Reimagining Freedom in the Twenty-First Century: Oakland, California : University of California Press.

Ray, Rashawn, Melissa Brown, Neil Fraistat and Edward Summers. 2017a. "Ferguson and the Death of Michael Brown on Twitter: \#Blacklivesmatter, \#Tcot, and the Evolution of Collective Identities." Ethnic and Racial Studies 40(11):1797-813. doi: 10.1080/01419870.2017.1335422.

Ray, Rashawn, Melissa Brown and Wendy Laybourn. 2017. "The Evolution of \#Blacklivesmatter on Twitter: Social Movements, Big Data, and Race." Ethnic and Racial Studies 40(11):1795-96. doi: 10.1080/01419870.2017.1335423.

Ray, Rashawn and Alexandra Gibbons. 2021, "Why Are States Banning Critical Race Theory?": Brookings. Retrieved 11/20/21, 2021 (https://www.brookings.edu/blog/fixgov/2021/07/02/why-are-statesbanning-critical-race-theory/).

Ray, Victor Erik, Antonia Randolph, Megan Underhill and David Luke. 2017b. "Critical Race Theory, AfroPessimism, and Racial Progress Narratives." Sociology of Race and Ethnicity 3(2):147-58. doi: $10.1177 / 2332649217692557$.

Reynolds-Stenson, Heidi. 2017. "Protesting the Police: Anti-Police Brutality Claims as a Predictor of Police Repression of Protest." Social Movement Studies 17(1):48-63. doi: 10.1080/14742837.2017.1381592.

Richie, Beth. 2012. Arrested Justice Black Women, Violence, and America's Prison Nation: New York : New York University Press, c2012.

Rios, Victor M. 2015. "Policed, Punished, Dehumanized." Pp. 59-80 in Deadly Injustice: Trayvon Martin, Race, and the Criminal Justice System, edited by D. Johnson, P. Y. Warren and A. Farrell New York: NYU Press. 
Robinson, Alisa. 2021, "Elephrame BIm Chart", https://elephrame.com/textbook/BLM/chart. Retrieved 11/16/21, 2021 (https://elephrame.com/textbook/BLM/chart).

Robinson, Randall. 2000. The Debt : What America Owes to Blacks. New York: Dutton.

Robnett, Belinda. 2020. "Defensive Adaptations: Naacp Responses to the Us Post-Racial Project 19701990." Pp. 26-62 in Racialized Protest and the State, edited by H. Johnston and P. Oliver: Routledge.

Rogers, Jamala. 2015. Ferguson Is America: Roots of Rebellion. St. Louis, Missouri: Mira Digital Publishing.

Rothman, Jay. 2006. "Identity and Conflict: Collaboratively Addressing Policy-Community Conflict in Cincinnati, Ohio." Ohio State Journal on Dispute Resolution 22:105.

Rupp, Leila J. and Verta A. Taylor. 1987. Survival in the Doldrums : The American Women's Rights Movement, 1945 to the 1960s. New York: Oxford University Press.

Santoro, Wayne A. and Max Fitzpatrick. 2015. "'The Ballot or the Bullet": The Crisis of Victory and the Institutionalization and Radicalization of the Civil Rights Movement." Mobilization 20(2):207-29.

Schatmeier, Elliot Harvey. 2012. "Reforming Police Use-of-Force Practices: A Case Study of the Cincinnati Police Department." Colum. JL \& Soc. Probs. 46:539.

Seguin, Charles. 2016. "Cascades of Coverage: Dynamics of Media Attention to Social Movement Organizations." Social Forces 94(3):997-1020. doi: 10.1093/sf/sov085.

Shemtov, Ronit. 1999. "Taking Ownership of Environmental Problems: How Local Nimby Groups Expand Their Goals." Mobilization 4(1):91-106.

Shi, Lan. 2009. "The Limit of Oversight in Policing: Evidence from the 2001 Cincinnati Riot." Journal of Public Economics 93(1):99-113. doi: https://doi.org/10.1016/j.jpubeco.2008.07.007.

Simi, Pete and Robert Futrell. 2020. "Active Abeyance, Political Opportunity, and the "New" White Supremacy." Pp. 112-39 in Racialized Protest and the State: Resistance and Repression in a Divided America, edited by H. Johnston and P. Oliver. Oxford UK and New York NY: Routledge.

Soule, Sarah, Doug McAdam, D. McCarthy John and Susan Olzak. n.d. "Dynamics of Collective Action." http://web.stanford.edu/group/collectiveaction/cgi-bin/drupal/.

Steijns, Jeffrey. 2017. "From" the Cincinnati Effect" to" the Ferguson Effect": Media's Growing Involvement in Police Brutality against Black Citizens." Faculty of Humanities, Leiden University.

Stillerman, Joel. 2020. "The Negro Labor Committee and the Dilemmas of Black Trade Unionism in New York City, 1925-1950." SocArXiv:https://osf.io/preprints/socarxiv/3hq86/.

Stone, Amy L. 2016. "The Impact of Anti-Gay Politics on the Lgbtq Movement." Sociology Compass 10(6):459-67. doi: https://doi.org/10.1111/soc4.12373.

Taylor, Keeanga-Yamahtta. 2016. From \#Blacklivesmatter to Black Liberation. Chicago, Illinois: Haymarket Books.

Taylor, Verta. 1989. "Social Movement Continuity: The Women's Movement in Abeyance." American Sociological Review 54(5):761-75.

Theoharis, Jeanne. 2006. "Black Freedom Studies: Re-Imagining and Redefining the Fundamentals1." History Compass 4(2):348-67. doi: 10.1111/j.1478-0542.2006.00318.x.

Theoharis, Jeanne. 2018. A More Beautiful and Terrible History: The Uses and Misuses of Civil Rights History. Boston, Massachusetts: Beacon Press.

Vliegenthart, Rens and Stefaan Walgrave. 2012. "The Interdependency of Mass Media and Social Movements." in The SAGE Handbook of Political Communication, edited by H. A. Semetko and M. Scammell. London: SAGE Publications Ltd.

Wada, Takeshi. 2004. "Event Analysis of Claim Making in Mexico: How Are Social Protests Transformed into Political Protests?". Mobilization: An International Journal 9(3):241-57. 
Watkins Liu, Callie. 2018. "The Anti-Oppressive Value of Critical Race Theory and Intersectionality in Social Movement Study." Sociology of Race and Ethnicity 4(3):306-21. doi: 10.1177/2332649217743771.

Watkins, S. Craig. 2001. "Framing Protest: News Media Frames of the Million Man March." Critical Studies in Media Communication 18(1):83-101. doi: 10.1080/15295030109367125.

Weddington, George. 2018. "The Fall of 2014: Recovering the Roots of the Black Lives Movement." Race, Politics, Justice (blog). (https://www.ssc.wisc.edu/soc/racepoliticsjustice/2018/09/01/the-fallof-2014-recovering-the-roots-of-the-black-lives-movement/).

Weddington, George. 2019. "Political Ontology and Race Research: A Response to "Critical Race Theory, Afro-Pessimism, and Racial Progress Narratives"." Sociology of Race and Ethnicity 5(2):278-88. doi: $10.1177 / 2332649218785921$.

West, Michael O. 1999. "Like a River: The Million Man March and the Black Nationalist Tradition in the United States." Journal of Historical Sociology 12(1):81-100. doi: 10.1111/1467-6443.00081.

Whittier, Nancy. 1997. "Political Generations, Micro-Cohorts, and the Transformation of Social Movements." American Sociological Review 62(5):760-78. doi: 10.2307/2657359.

Williams, Rhonda Y. 2015. Concrete Demands : The Search for Black Power in the 20th Century: New York, NY : Routledge, 2015.

Woods, Clyde A. 2017. Development Drowned and Reborn : The Blues and Bourbon Restorations in PostKatrina New Orleans: Athens, GA : University of Georgia Press, [2017].

Zamora, Sylvia and Chinyere Osuji. 2014. "Mobilizing African Americans for Immigrant Rights: Framing Strategies in Two Multi-Racial Coalitions." Latino Studies 12(3):424-48. doi: 10.1057/Ist.2014.47. 


\section{NOTES}

${ }^{1}$ Black Lives Matter is a Twitter hashtag that caught on as a movement slogan and the name of an organization, Black Lives Matter Global Network Foundation, founded by three activists, Patrisse Cullors, Alicia Garza, and Opal Tometi. The broader movement included many other organizations and activists. We use the phrase Black Lives Movement to encompass this larger movement.

${ }^{2}$ We capitalize White as well as Black partly for consistency; all other "race names" are capitalized, including the synonyms European American and Caucasian. White people are a collective identity group in the context of this paper. We recognize that some scholars capitalize Black but not White for theoretical or political reasons. We do not capitalize in contexts where the reference is merely to physical appearance. We use Black and African American interchangeably in this paper.

${ }^{3}$ The New York Times and Associated Press Worldstream files cover the entire period 19942010. The Los Angeles Times - Washington Post files are for 1994-8 and 2003-9. There are also stories for 2010 from the Washington Post Bloomberg service.

${ }^{4}$ These are (1) the aggregate event of four days of rioting in Cincinnati in 2001; (2) the Million Man March in 1995; (3) the big rally in Jena, Louisiana in 2007; and (4) the 2000 tourism boycott of South Carolina.

${ }^{5}$ The monthly number of articles roughly tracks the number of events (the correlation is high but not perfect, $\mathrm{r}=.80, \mathrm{r}^{2}=.64$ ), while the correlation between the number of participants per month and the number of articles per month is low $\left(\mathrm{r}=.27, \mathrm{r}^{2}=.07\right.$.

${ }^{6}$ Because some articles mention multiple issue clusters, sums of articles mentioning issues does not equal the total number of articles. Of the 1,210 articles, 138 (12\%) mentioned more than one specific issue cluster; 51 (4\%) mentioned clusters that are in different issue groups.

${ }^{7}$ Rosa Parks was 81 in 1994 when these data begin and died in October 2005. She spoke at the Million Man March and the Million Women march and was awarded a medal in 1999. Most mentions are of events around her funeral and the $50^{\text {th }}$ anniversary of the Montgomery Bus Boycott a few weeks later. In other cases, she is cited as a symbol, not as a person present at the event. Coretta Scott King died a few months after Parks, in January 2006. She issued statements around a number of issues, was often mentioned in articles about memorials of Dr. King, and was mentioned in events that occurred shortly after her death.

${ }^{8}$ Later investigations and testimony suggested that the man had been accidentally run over by his drunken companions rather than intentionally killed.

${ }^{9}$ Our data include the rally in Chicago the night Obama was elected as an event, because newswire stories emphasized the reactions of Black Civil Rights leaders, but we did not record other election-night celebrations. We did not record Obama's inauguration or associated events, but did record two small events about people organizing to attend or celebrate the inauguration.

${ }^{10}$ The One Nation Rally was widely covered in the Black newspapers, which we are still in the process of coding as an extension to the current project, while the Colbert/Stewart rally does not seem to have been of much interest to Black news sources. 
Oliver, Lim, Matthews, Hanna. Black Protests in the US, 1994-2010

Details about Methods

Data Source: Newswires available in Annotated English Gigaword (AGW), available by purchase from the Linguistic Data Consortium (Associated Press Worldstream, New York Times, Los Angeles Times/Washington Post).

We used a protest-relevant keyword search string (boycott* OR press conference OR news conference OR protest* OR strik* OR rally OR ralli* OR riot* OR sit-in OR occupation OR mobiliz* OR blockage OR demonstrat* OR marchi* OR marche* NOT protestant*) and a Black/African American search string ((Black AND NOT Blacks) OR African* OR Afro*) to retrieve a large pool of articles from the AGW database. We used MPEDS, an open-source automated system developed by Alex Hanna (2017) to select the subset of articles that were likely to have information about protests. Hanna (2017) reports that classification errors by MPEDS mimic those of human coders in this inherently difficult task. An automated system for identifying locations in news articles from place names was used to further restrict protests to those in the US.

The original identification of events in news articles, what we call pass 1 coding, was done by undergraduate assistants generally working for course credit using the MPEDS Annotation Interface (MAI) developed by Alex Hanna and available at https://github.com/mpeds/mpeds-coder. MAl is specifically designed for protest event research and can be modified for each project's specific needs. Coders identify events in articles, answer questions about the events, and highlight text about them. Output of the MAl is a table of information that is input to our pass 2 system, implemented in Microsoft Access, in which events are matched up between articles and the initial coding is used to created authorized events. Pass 2 coding includes reviewing and correcting pass 1 decisions. The first three authors of this paper did the pass 2 coding, as well as additional coding, review, and correction of errors.

Central to our method is a relational database that establishes strong verifiable links between articles and events which permit us to review and correct prior work. Coding protest event data and matching events up between articles involves adjudicating many ambiguous cases and is difficult to do consistently and without errors. Our procedures involve several iterations of checking and errorcorrection, and we return to the database and correct errors if we find them in the process of analysis. We record the export date for any published analysis. The final export date for the data reported in this paper and released in the replication package is 2022-2-7.

As the paper indicates, in addition to events by Black actors, we retain anti-Black or pro-White events and events by other actors if they appeared in articles mentioning Black events.

Our methods involve coding events that are aggregates of other events. These include both unspecific references to multiple past events with phrases such as "protests last week" and events that are made up of subevents, such as protests with counter-protests or coordinated protests in multiple cities. We record the relations among the events in our data. For the descriptive purposes of this paper, we have counted all events, including those that are aggregates of other events, as this does not affect our goal of providing a broad view of the Black movement. We flag aggregate events that include other events in the data, so that we do not double-count participants. 
For each event, we identify its specific issue, the thing the event is "about." This is usually readily identified in news articles because this is how they are written. A specific issue cluster is a set of events about the same specific issue. Again, these clusters are usually readily identified because that is how the articles are written. There are some cases in which researcher judgement was involved in defining specific issue clusters, with the general principle being that events were described in articles as being related to each other in article narratives about a given topic. An event can belong to more than one specific issue cluster, but in this paper each event is associated only with one cluster, either its primary cluster or, in the case of clusters nested within clusters, with the most overarching cluster.

Grouping these specific issues into issue groups is a researcher-driven process, as the researcher creates abstract categories in line with researcher purposes or theorizing.

Because our methods simultaneously record events and news coverage of events, we can describe both "what happened" according to the news sources and the volume or content of news coverage of different events. After providing basic quantitative overviews, this paper provides a qualitative discussion of the "big stories" that received a great deal of news coverage.

Hanna, Alex. 2017. "MPEDS: Automating the Generation of Protest Event Data." Deposited at SocArXiv https://osf.io/preprints/socarxiv/xuqmv. 
Table A1. Summary of the largest clusters that were covered in more than 20 articles or had more than 20 events.

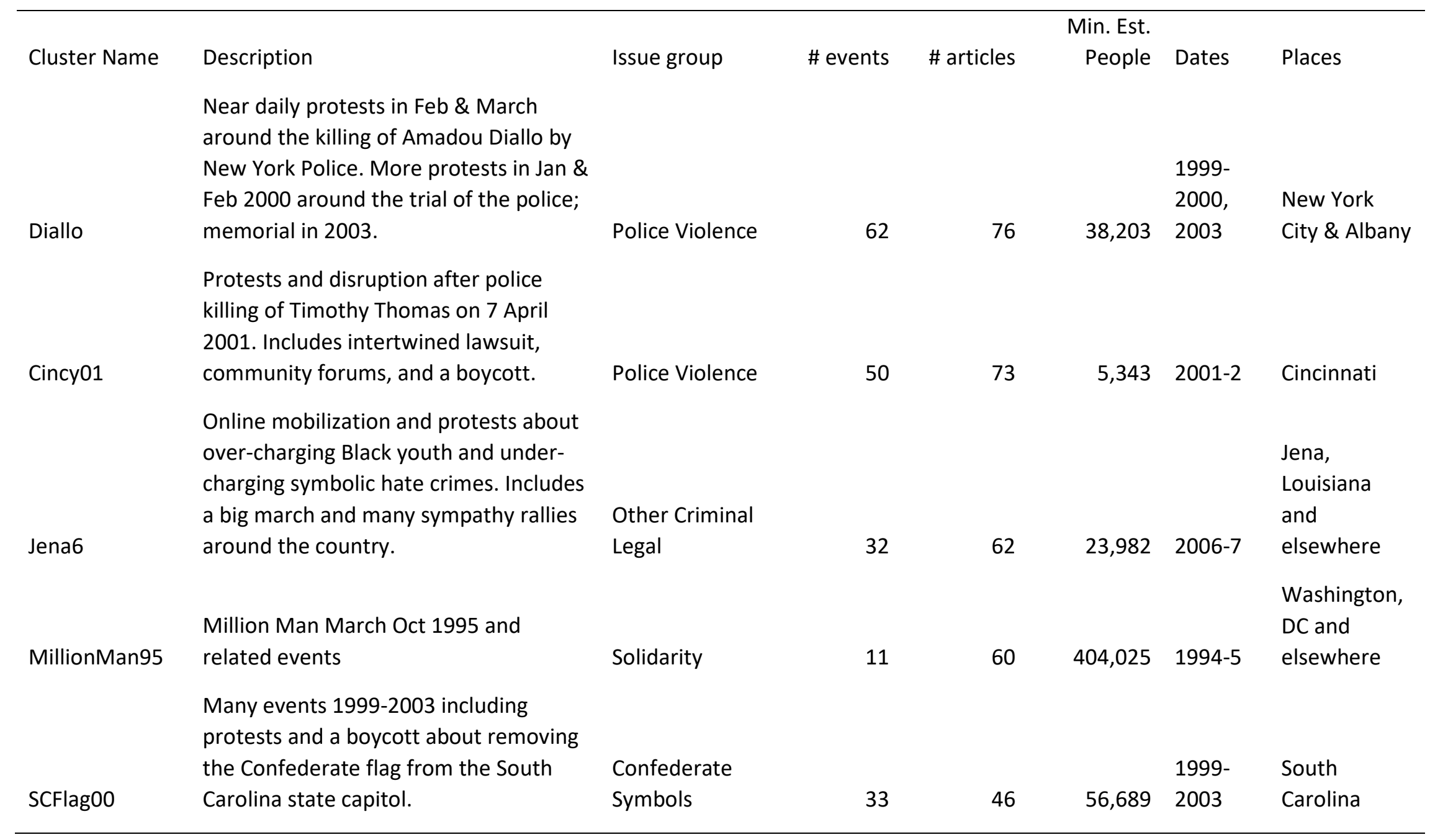




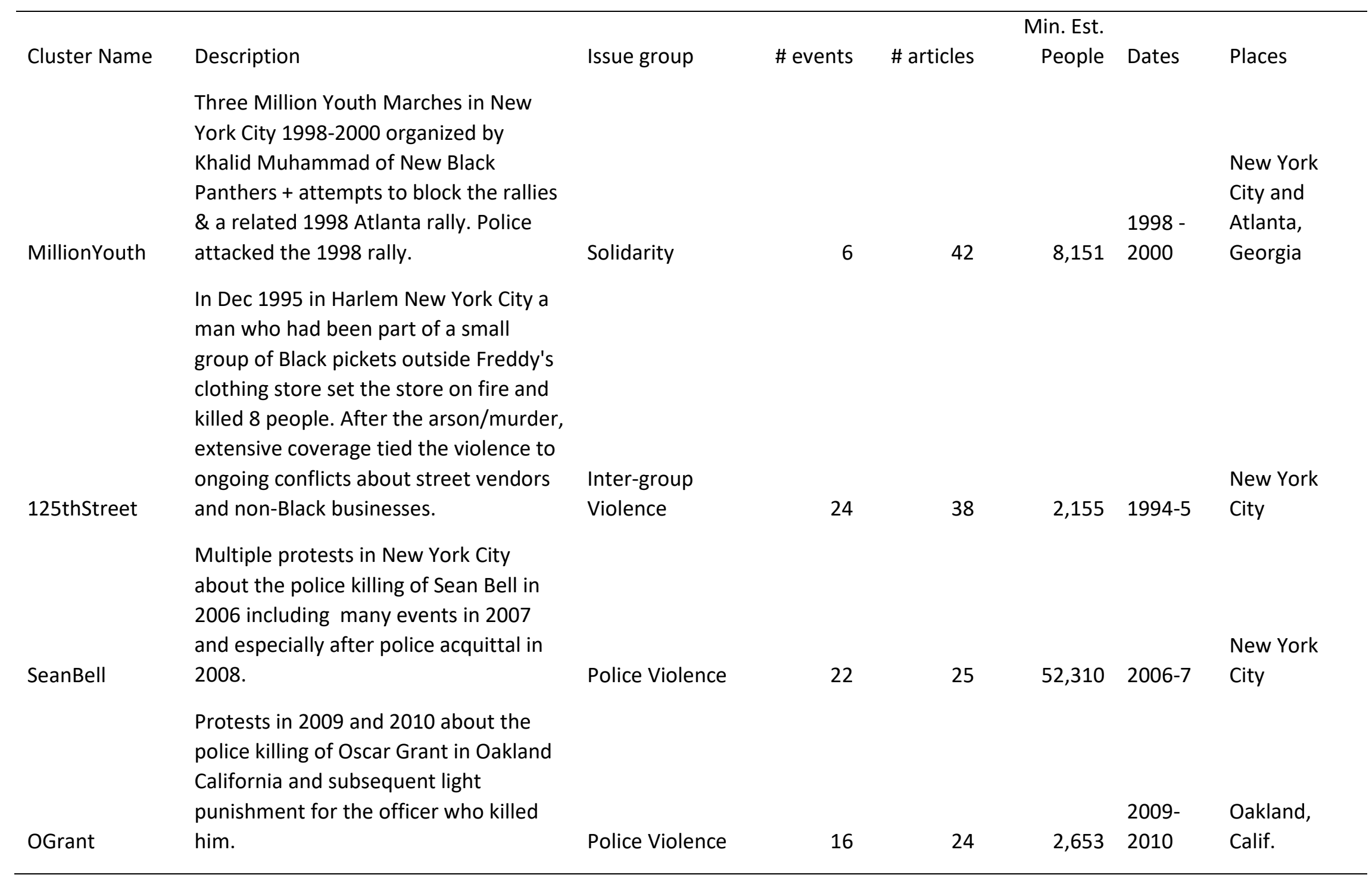




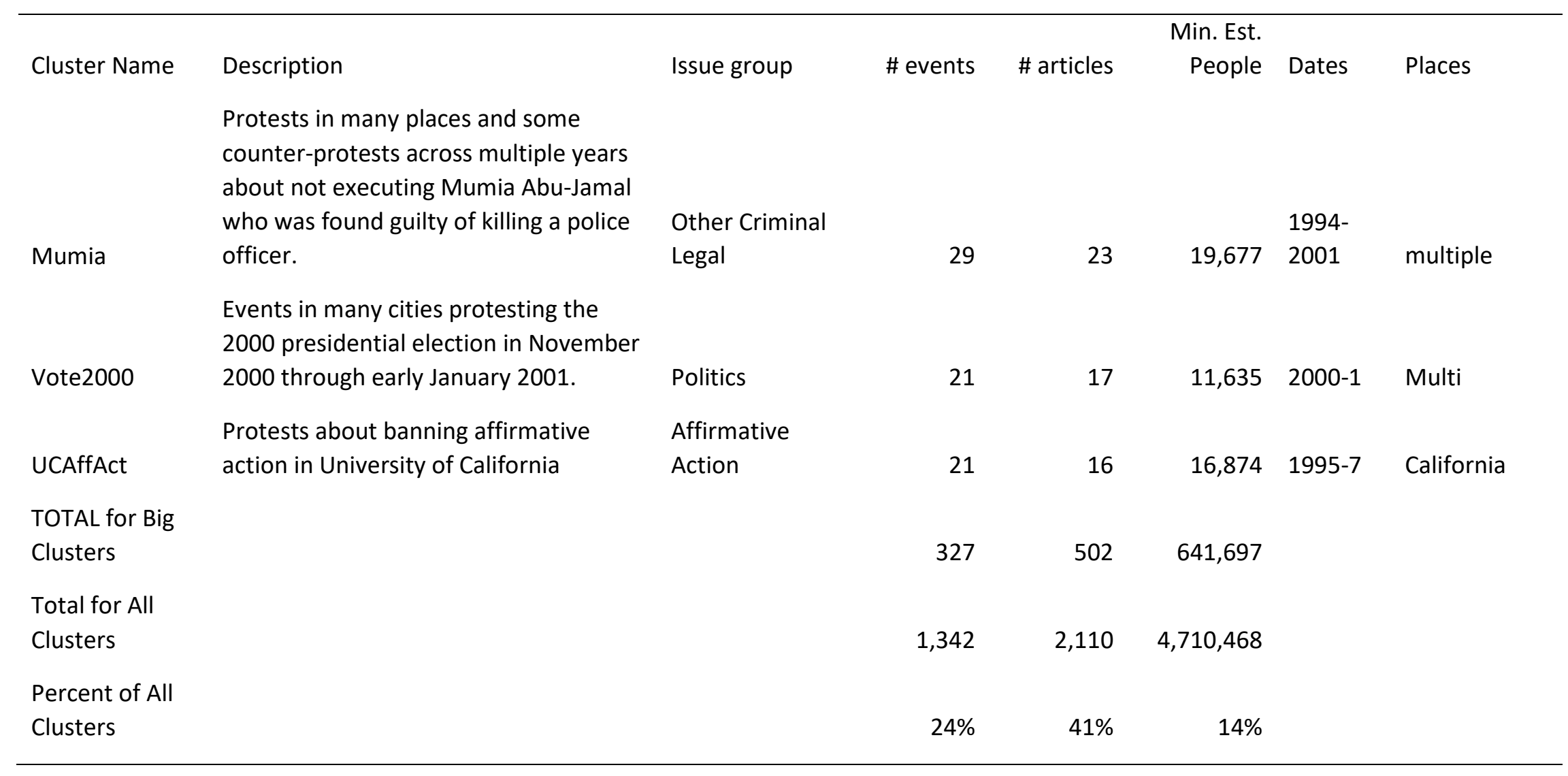


Table A2 Number of issue clusters, events, articles, and participants associated with issues

\begin{tabular}{|c|c|c|c|c|c|}
\hline & \# Clusters & \# Events & \# Articles & $\begin{array}{r}\text { \# Participants } \\
\text { (min) }\end{array}$ & $\begin{array}{r}\text { \# Participants } \\
\text { (max) }\end{array}$ \\
\hline \multicolumn{6}{|l|}{ Police Violence } \\
\hline NY Louima & 1 & 7 & 12 & 9,510 & 24,790 \\
\hline NY Diallo & 1 & 62 & 76 & 38,203 & 122,447 \\
\hline NY Dorismond & 1 & 15 & 11 & 13,989 & 36,884 \\
\hline NY Bell & 1 & 22 & 25 & 52,310 & 59,640 \\
\hline Cincinnati & 1 & 50 & 73 & 5,343 & 14,590 \\
\hline Oakland & 1 & 16 & 24 & 2,653 & 20,575 \\
\hline Police Violence - Other & 40 & 92 & 87 & 21,638 & 68,718 \\
\hline \multicolumn{6}{|l|}{ Other criminal legal } \\
\hline Charging - Jena6 & 1 & 32 & 66 & 23,982 & 83,032 \\
\hline Charging - Nooses 2007 & 1 & 15 & 15 & 920 & 1,737 \\
\hline Charging Hate Crimes - Other & 2 & 2 & 2 & 158 & 214 \\
\hline Charging - other & 5 & 19 & 14 & 50,668 & 204,940 \\
\hline Death Penalty - Mumia & 1 & 29 & 23 & 19,677 & 98,025 \\
\hline Death Penalty - Other & 4 & 12 & 8 & 3,075 & 28,880 \\
\hline Police - Pro-police & 3 & 3 & 3 & 4,505 & 15,030 \\
\hline Police - Other & 8 & 20 & 16 & 3,543 & 10,343 \\
\hline Legal - other & 7 & 11 & 7 & 5,567 & 14,330 \\
\hline \multicolumn{6}{|l|}{ Confederate Symbols } \\
\hline South Carolina Flag 2000 & 1 & 33 & 61 & 56,689 & 90,296 \\
\hline Georgia Flag 2000 & 1 & 7 & 13 & 465 & 1,585 \\
\hline Other & 22 & 48 & 35 & 5,371 & 45,105 \\
\hline \multicolumn{6}{|l|}{ Affirmative Action } \\
\hline Affirmative Action - California & 1 & 21 & 16 & 16,874 & 84,328 \\
\hline Affirmative Action - Other & 7 & 22 & 17 & 25,671 & 39,629 \\
\hline \multicolumn{6}{|l|}{ White Identity Groups } \\
\hline KKK vs NBP & 4 & 21 & 17 & 998 & 2,661 \\
\hline with Counter-protests & 10 & 29 & 18 & 2,088 & 5,388 \\
\hline Other & 25 & 52 & 35 & 11,905 & 27,498 \\
\hline \multicolumn{6}{|l|}{ Campus Issues } \\
\hline Rutgers & 1 & 8 & 12 & 1,234 & 2,420 \\
\hline Other & 14 & 43 & 22 & 8,690 & 19,785 \\
\hline \multicolumn{6}{|l|}{ Local Issues } \\
\hline New Orleans & 3 & 12 & 14 & 4,337 & 8,620 \\
\hline Community Violence & 10 & 16 & 13 & 8,081 & 31,865 \\
\hline School & 9 & 15 & 11 & 3,736 & 8,433 \\
\hline Economic & 9 & 15 & 11 & 1,697 & 5,400 \\
\hline Other & 12 & 22 & 15 & 18,752 & 56,166 \\
\hline \multicolumn{6}{|l|}{ Other Black Issues } \\
\hline Discrimination & 5 & 15 & 15 & 513 & 1,355 \\
\hline Reparations & 2 & 12 & 11 & 361 & 1,305 \\
\hline Media & 5 & 15 & 12 & 2,239 & 17,850 \\
\hline Speech \& Symbols & 12 & 26 & 19 & 1,906 & 6,530 \\
\hline Foreign Countries & 2 & 10 & 11 & 10,302 & 40,651 \\
\hline Other & 7 & 8 & 9 & 415 & 775 \\
\hline
\end{tabular}


Table A2 Number of issue clusters, events, articles, and participants associated with issues

\begin{tabular}{|c|c|c|c|c|c|}
\hline & \# Clusters & \# Events & \# Articles & $\begin{array}{r}\text { \# Participants } \\
\text { (min) }\end{array}$ & $\begin{array}{r}\text { \# Participants } \\
\text { (max) }\end{array}$ \\
\hline \multicolumn{6}{|l|}{ Organizational } \\
\hline \multicolumn{6}{|l|}{ Inter-group Violence } \\
\hline 125th Street & 1 & 24 & 38 & 2,155 & 5,398 \\
\hline LA Jails 05 & 1 & 20 & 18 & 3,558 & 6,001 \\
\hline Hate Crimes & 12 & 24 & 20 & 6,915 & 60,442 \\
\hline Other Collective & 12 & 18 & 18 & 4,972 & 15,407 \\
\hline \multicolumn{6}{|l|}{ Coalition Issues } \\
\hline Million Moms (guns) & 1 & 2 & 8 & 500,000 & 980,000 \\
\hline Abortion & 4 & 6 & 4 & 108,520 & 529,790 \\
\hline Gay Rights & 7 & 12 & 11 & 205,436 & 427,325 \\
\hline Higher Education & 2 & 9 & 3 & 15,964 & 17,427 \\
\hline Immigrants \& Other Groups & 16 & 38 & 37 & 106,678 & 433,302 \\
\hline Iraq War & 2 & 7 & 8 & 1,900 & 52,180 \\
\hline Religion & 2 & 5 & 4 & 302,305 & $1,020,560$ \\
\hline Welfare Issues & 2 & 2 & 5 & 200,180 & $1,000,220$ \\
\hline \multicolumn{6}{|l|}{ Workers } \\
\hline Discrimination & 11 & 36 & 21 & 2,074 & 6,667 \\
\hline Strikes & 16 & 36 & 25 & 253,624 & 410,085 \\
\hline Workers-other & 13 & 20 & 15 & 19,968 & 39,965 \\
\hline \multicolumn{6}{|l|}{ Political Issues } \\
\hline Vote2000 & 1 & 21 & 17 & 11,635 & 43,095 \\
\hline Inaugurations - 2001 & 1 & 4 & 13 & 9,200 & 18,800 \\
\hline Inaugurations - 2005 & 1 & 5 & 20 & 12,750 & 38,200 \\
\hline Racialized - Beck & 1 & 3 & 23 & 112,000 & 405,000 \\
\hline Racialized - Other & 3 & 6 & 12 & 6,710 & 7,800 \\
\hline Political-other & 15 & 26 & 34 & 577,037 & 943,069 \\
\hline \multicolumn{6}{|l|}{ History } \\
\hline MLK Day 2000 & 1 & 7 & 1 & 80,760 & 125,400 \\
\hline Commemorations & 27 & 61 & 55 & 74,909 & 415,929 \\
\hline Truth-telling & 14 & 22 & 20 & 976 & 3,960 \\
\hline \multicolumn{6}{|l|}{ Solidarity } \\
\hline Million Man March & 1 & 11 & 60 & 404,025 & $1,007,100$ \\
\hline Million Youth (KAM) & 1 & 6 & 42 & 8,151 & 9,601 \\
\hline Millions-other & 4 & 25 & 22 & 692,573 & $2,849,509$ \\
\hline KAM other & 3 & 5 & 7 & 570 & 1,570 \\
\hline Festivals-policing issues & 3 & 7 & 7 & 420,000 & 735,000 \\
\hline Solidarity-other & 4 & 4 & 4 & 20,100 & 37,000 \\
\hline Total & 432 & 1,342 & 1,435 & $4,606,694$ & $12,968,476$ \\
\hline
\end{tabular}


Table A3 Number of clusters with articles including name, by issue group

\begin{tabular}{|c|c|c|c|c|c|c|c|c|c|c|c|c|c|c|c|}
\hline & $\begin{array}{r}\text { Police } \\
\text { Violence }\end{array}$ & $\begin{array}{r}\text { Other } \\
\text { criminal } \\
\text { legal }\end{array}$ & $\begin{array}{r}\text { Confederate } \\
\text { Symbols }\end{array}$ & $\begin{array}{r}\text { Affirmative } \\
\text { Action }\end{array}$ & $\begin{array}{r}\text { White } \\
\text { Identity } \\
\text { Groups }\end{array}$ & $\begin{array}{r}\text { Campus } \\
\text { Issues }\end{array}$ & $\begin{array}{l}\text { Local } \\
\text { Issues }\end{array}$ & $\begin{array}{l}\text { Other } \\
\text { Black } \\
\text { Issues }\end{array}$ & $\begin{array}{l}\text { Organi- } \\
\text { zational }\end{array}$ & $\begin{array}{r}\text { Inter- } \\
\text { group } \\
\text { Violence }\end{array}$ & $\begin{array}{r}\text { Coalition } \\
\text { Issues }\end{array}$ & Workers & $\begin{array}{r}\text { Political } \\
\text { Issues }\end{array}$ & History & Solidarity \\
\hline \multicolumn{16}{|l|}{ Person or Organization } \\
\hline NAACP & 14 & 6 & 11 & 5 & 5 & 2 & 5 & 8 & 5 & 5 & 11 & 6 & 9 & 9 & 6 \\
\hline Al Sharpton & 13 & 5 & 0 & 0 & 4 & 2 & 9 & 7 & 0 & 5 & 3 & 5 & 7 & 2 & 6 \\
\hline Jesse Jackson & 7 & 9 & 3 & 3 & 3 & 1 & 5 & 7 & 2 & 4 & 4 & 7 & 5 & 9 & 4 \\
\hline \multicolumn{16}{|l|}{ NAACP or Sharpton or } \\
\hline Jackson & 27 & 14 & 11 & 5 & 11 & 4 & 14 & 17 & 5 & 10 & 12 & 16 & 12 & 18 & 8 \\
\hline SCLC & 2 & 4 & 4 & 1 & 0 & 0 & 3 & 2 & 1 & 0 & 1 & 2 & 2 & 6 & 3 \\
\hline Martin Luther King III & 1 & 3 & 2 & 1 & 0 & 0 & 0 & 1 & 1 & 0 & 0 & 0 & 3 & 3 & 3 \\
\hline Coretta Scott King & 1 & 0 & 3 & 0 & 1 & 0 & 1 & 0 & 0 & 0 & 3 & 0 & 0 & 10 & 1 \\
\hline Rosa Parks & 2 & 1 & 1 & 1 & 1 & 1 & 0 & 2 & 0 & 0 & 0 & 2 & 0 & 5 & 2 \\
\hline \multicolumn{16}{|l|}{ Rainbow/PUSH (no } \\
\hline Jackson) & 1 & 0 & 0 & 0 & 1 & 0 & 2 & 0 & 0 & 0 & 1 & 0 & 1 & 1 & 0 \\
\hline Ben Chavis (no NAACP) & 0 & 0 & 0 & 0 & 0 & 0 & 0 & 0 & 0 & 0 & 1 & 0 & 0 & 0 & 3 \\
\hline \multicolumn{16}{|l|}{ Kweisi Mfume (no } \\
\hline NAACP) & 1 & 0 & 0 & 0 & 0 & 0 & 0 & 0 & 0 & 0 & 0 & 0 & 0 & 0 & 1 \\
\hline Louis Farrakhan & 1 & 3 & 0 & 0 & 1 & 0 & 1 & 1 & 6 & 2 & 2 & 0 & 1 & 1 & 10 \\
\hline \multicolumn{16}{|l|}{ Khalid Abdul } \\
\hline Muhammad & 0 & 0 & 0 & 0 & 1 & 0 & 0 & 1 & 0 & 0 & 0 & 0 & 0 & 0 & 5 \\
\hline Malcolm Zulu Shabazz & 2 & 0 & 0 & 0 & 1 & 0 & 2 & 0 & 1 & 2 & 0 & 0 & 0 & 1 & 1 \\
\hline \multicolumn{16}{|l|}{$\begin{array}{l}\text { Nation of Islam (no } \\
\text { Farrakhan, } \\
\text { Muhammad, or }\end{array}$} \\
\hline Shabazz) & 4 & 2 & 0 & 0 & 1 & 0 & 2 & 2 & 0 & 1 & 1 & 0 & 0 & 0 & 2 \\
\hline \multicolumn{16}{|l|}{ New Black Panthers (no } \\
\hline Shabazz) & 2 & 4 & 0 & 0 & 3 & 0 & 0 & 1 & 0 & 0 & 0 & 0 & 1 & 0 & 0 \\
\hline \multicolumn{16}{|l|}{ Civil Liberties Union } \\
\hline (ACLU \& affiliates) & 9 & 3 & 1 & 2 & 3 & 0 & 0 & 3 & 1 & 1 & 3 & 0 & 0 & 1 & 2 \\
\hline AFL-CIO & 0 & 0 & 0 & 1 & 0 & 0 & 1 & 0 & 0 & 0 & 2 & 8 & 3 & 0 & 0 \\
\hline \multicolumn{16}{|l|}{ National Organization } \\
\hline for Women & 0 & 1 & 0 & 1 & 0 & 0 & 1 & 0 & 0 & 0 & 4 & 0 & 1 & 1 & 2 \\
\hline Amnesty International & 0 & 1 & 0 & 0 & 0 & 0 & 0 & 0 & 0 & 0 & 1 & 0 & 0 & 0 & 0 \\
\hline Anti-Racist Action & 0 & 0 & 0 & 0 & 3 & 0 & 0 & 0 & 0 & 0 & 0 & 0 & 0 & 0 & 0 \\
\hline \multicolumn{16}{|l|}{ Any of the listed names } \\
\hline or groups & 29 & 19 & 13 & 5 & 16 & 4 & 19 & 20 & 10 & 11 & 17 & 22 & 13 & 24 & 13 \\
\hline \multicolumn{16}{|l|}{ None of the listed } \\
\hline names or groups & 34 & 18 & 14 & 5 & 28 & 13 & 28 & 18 & 0 & 21 & 27 & 21 & 15 & 24 & 6 \\
\hline Total & 46 & 32 & 24 & 8 & 39 & 15 & 43 & 33 & 10 & 26 & 36 & 40 & 22 & 42 & 16 \\
\hline
\end{tabular}

